\title{
Granule-Like Neurons at the Hilar/CA3 Border after Status Epilepticus and Their Synchrony with Area CA3 Pyramidal Cells: Functional Implications of Seizure-Induced Neurogenesis
}

\author{
Helen E. Scharfman, ${ }^{1,2}$ Jeffrey H. Goodman, ${ }^{1}$ and Anne L. Sollas ${ }^{1}$ \\ ${ }^{1}$ Center for Neural Recovery and Rehabilitation Research, Helen Hayes Hospital, West Haverstraw, New York 10993-1195, \\ and 2 Departments of Pharmacology and Neurology, Columbia University, New York, New York 10032
}

A group of neurons with the characteristics of dentate gyrus granule cells was found at the hilar/CA3 border several weeks after pilocarpine- or kainic acid-induced status epilepticus. Intracellular recordings from pilocarpine-treated rats showed that these "granule-like" neurons were similar to normal granule cells (i.e., those in the granule cell layer) in membrane properties, firing behavior, morphology, and their mossy fiber axon. However, in contrast to normal granule cells, they were synchronized with spontaneous, rhythmic bursts of area CA3 pyramidal cells that survived status epilepticus. Saline-treated controls lacked the population of granule-like cells at the hilar/CA3 border and CA3 bursts.

In rats that were injected after status epilepticus with bromodeoxyuridine (BrdU) to label newly born cells, and also labeled for calbindin $D_{28 k}$ (because it normally stains granule cells), many double-labeled neurons were located at the hilar/ CA3 border. Many BrdU-labeled cells at the hilar/CA3 border also were double-labeled with a neuronal marker (NeuN). Taken together with the recent evidence that granule cells that are born after seizures can migrate into the hilus, the results suggest that some newly born granule cells migrate as far as the CA3 cell layer, where they become integrated abnormally into the CA3 network, yet they retain granule cell intrinsic properties. The results provide insight into the physiological properties of newly born granule cells in the adult brain and suggest that relatively rigid developmental programs set the membrane properties of newly born cells, but substantial plasticity is present to influence their place in pre-existing circuitry.

Key words: epilepsy; plasticity; cell migration; dentate gyrus; kainic acid; pilocarpine
The pilocarpine and kainic acid animal models of epilepsy are two of the most common experimental tools in epilepsy research (Nadler, 1981; Ben-Ari, 1985; Turski et al., 1989; Mello et al., 1993; Dudek et al., 1994; Sperk, 1994). In adult rats, systemic administration of either pilocarpine, a muscarinic agonist, or kainic acid, an agonist of the kainic acid subtype of glutamate receptor, leads to status epilepticus, which lasts for several hours. Several days to weeks after status, spontaneous limbic seizures often occur and continue intermittently thereafter (Nadler, 1981; Ben-Ari, 1985; Tauck and Nadler, 1985; Turski et al., 1989; Mello et al., 1993; Liu et al., 1994; Sperk 1994; Hellier et al., 1998; Motte et al., 1998).

Brain damage after pilocarpine- and kainic acid-induced status epilepticus is usually severe and widespread. In the hippocampus, neuronal loss in the pyramidal cell layers and hilar region is common, whereas the dentate gyrus granule cells are relatively resistant (Nadler, 1981; Mello et al., 1993; Obenaus et al., 1993; Liu et al., 1994; Buckmaster and Dudek, 1997; Okazaki et al., 1999). A common finding is mossy fiber "sprouting," which refers to the abnormal growth of dentate granule cell axons (the mossy fibers) into the inner molecular layer of the dentate gyrus. Similar pathology has been reported in human temporal lobe epilepsy (TLE; Margerison and Corsellis, 1966; Babb and Brown, 1987; Meldrum and Bruton, 1992; Sutula et al., 1989; Babb et al., 1991; Mathern et al., 1997).

As a result of the studies of pathology in animal models and TLE, hilar and pyramidal cell loss has often been associated with limbic epileptogenesis. However, previous studies of pilocarpine-

Received March 31, 2000; revised May 5, 2000; accepted May 12, 2000.

This work was supported by National Institutes of Health Grant 38285 to H.E.S. We thank Drs. Gyuri Buzsáki, Sam Deadwyler, Fred Gage, Dan Lowenstein, Timothy Pedley, Philip Schwartzkroin, and Karen Smith for discussions during the course of this study and comments on an earlier form of this manuscript, and Annmarie Curcio and Ruth Marshall for technical and secretarial assistance.

Correspondence should be addressed to Helen Scharfman, Center for Neural Recovery and Rehabilitation Research, Helen Hayes Hospital, Route 9W,West Haverstraw, NY 10993-1195. E-mail: scharfmanh@helenhayeshosp.org.

Copyright (C) 2000 Society for Neuroscience $0270-6474 / 00 / 206144-15 \$ 15.00 / 0$ and kainic acid-treated rats showed that there can be some preservation of hilar and CA3 pyramidal neurons (Buckmaster and Dudek, 1997; Okazaki et al., 1999). Therefore, it was of interest to examine which neurons survived. To address this issue, immunocytochemical experiments were performed after pilocarpine or kainic acid treatment, using antibodies to a number of neuronal markers. To our surprise, immunocytochemistry using an antibody to the calcium-binding protein calbindin $\mathrm{D}_{28 \mathrm{~K}}(\mathrm{CaBP})$ demonstrated a cluster of immunoreactive cells at the hilar/CA3 border that, to our knowledge, has not been previously reported, either in normal or epileptic conditions. CaBP normally stains granule cells and a few scattered GABA neurons ("interneurons"; Baimbridge and Miller, 1982; Sloviter, 1989; Tóth and Freund, 1992; Seress et al., 1993). After seizures, CaBP expression can decrease in granule cells (Maglóczky et al., 1997; Sloviter et al., 1991; Tønder et al., 1994; Shetty and Turner, 1995; Yang et al., 1997; Nagerl et al., 2000) (but see Lowenstein et al., 1991), but novel cell types expressing $\mathrm{CaBP}$ in the hilus or CA3 have not been described.

This report presents morphological, immunohistochemical, and electrophysiological evidence that the CaBP-immunoreactive cells at the hilar/CA3 border are related to granule cells. The hypothesis is raised that they represent newly born granule cells that migrated from their site of origin to the hilar/CA3 border. This hypothesis is based on a number of studies that illustrate the plasticity in the dentate gyrus after seizures. For example, seizures can lead to altered location of granule cells, as demonstrated by dispersion of the granule cell layer (Houser, 1990). Seizures can also lead to the extension of "basal" dendrites of granule cells into the hilar region (Spigelman et al., 1998; Buckmaster and Dudek, 1999). Finally, seizures increase granule cell neurogenesis, and it has been shown that the newly born cells can migrate into the hilus (Parent et al., 1997).

Dentate granule cell neurogenesis is a process that normally occurs throughout life (Gould and Cameron, 1996; Gage et al., 1998). Many newly born cells arise from the subgranular proliferative zone, a lamina between the granule cell layer and the hilus 
Table 1. Membrane properties of granule-like neurons and granule cells in the granule cell layer of pilocarpine-treated rats and saline-treated controls

\begin{tabular}{|c|c|c|c|c|c|c|c|c|c|c|c|c|}
\hline & \multirow[b]{2}{*}{$\mathrm{RMP}(\mathrm{mV})$} & \multirow[b]{2}{*}{$\mathrm{R}_{\text {in }}(\mathrm{M} \Omega)$} & \multirow[b]{2}{*}{$\tau(\mathrm{msec})$} & \multicolumn{2}{|l|}{ AP amp } & \multicolumn{3}{|l|}{ AP slope } & \multicolumn{2}{|l|}{ AP dur } & \multicolumn{2}{|l|}{ AHP } \\
\hline & & & & $\begin{array}{l}\text { Total amp } \\
(\mathrm{mV})\end{array}$ & $\begin{array}{l}\text { From thresh. } \\
(\mathrm{mV})\end{array}$ & $\begin{array}{l}\text { Max. rise } \\
(\mathrm{V} / \mathrm{S})\end{array}$ & $\begin{array}{l}\text { Max. decay } \\
(\mathrm{V} / \mathrm{S})\end{array}$ & $\begin{array}{l}\mathrm{dv} / \mathrm{dt} \text { ratio } \\
\text { (rise/decay) }\end{array}$ & $\begin{array}{l}\text { Total dur. } \\
(\mathrm{msec})\end{array}$ & $\begin{array}{l}1 / 2 \text { dur. } \\
\text { (msec) }\end{array}$ & $\begin{array}{l}\text { Peak amp. } \\
(\mathrm{mV})\end{array}$ & $\begin{array}{l}\text { Total dur. } \\
(\mathrm{msec})\end{array}$ \\
\hline \multicolumn{13}{|c|}{ Pilocarpine-treated } \\
\hline \multicolumn{13}{|c|}{ Granule-like neurons } \\
\hline Mean & -75.8 & 58.1 & 9.25 & 105.4 & 77.2 & 401 & 75 & 5.5 & 1.64 & 0.17 & 6.3 & 5.33 \\
\hline SEM & 1.9 & 6.5 & 4.8 & 4.4 & 2.0 & 31 & 6 & 0.4 & 0.10 & 0.01 & 1.2 & 0.99 \\
\hline$n$ & 6 & 8 & 8 & 8 & 8 & 8 & 8 & 8 & 8 & 8 & 6 & 6 \\
\hline \multicolumn{13}{|c|}{ Granule cells in the granule cell layer } \\
\hline Mean & -72.8 & 43.1 & 8.14 & 100.3 & 79.2 & 434 & 89 & 5.0 & 1.70 & 0.20 & 8.0 & 7.00 \\
\hline SEM & 1.8 & 2.9 & 1.1 & 1.3 & 4.0 & 36 & 6 & 0.3 & 0.11 & 0.02 & 0.9 & 0.91 \\
\hline$n$ & 7 & 8 & 7 & 8 & 8 & 11 & 11 & 11 & 11 & 10 & 8 & 7 \\
\hline \multicolumn{13}{|c|}{ Saline-treated } \\
\hline \multicolumn{13}{|c|}{ Granule cells in the granule cell layer } \\
\hline Mean & -71.5 & 57.5 & 11.2 & 103.6 & 74.6 & 420 & 92 & 4.8 & 1.51 & 0.19 & 7.2 & 5.20 \\
\hline SEM & 2.9 & 7.5 & 2.4 & 7.8 & 1.9 & 55 & 9 & 0.2 & 0.07 & 0.03 & 1.3 & 0.56 \\
\hline$n$ & 4 & 4 & 4 & 5 & 5 & 5 & 5 & 5 & 5 & 5 & 5 & 5 \\
\hline \multicolumn{13}{|c|}{ Granule cells $50-100 \mu \mathrm{m}$ from the granule cell layer/hilar border } \\
\hline Mean & -72.0 & 61.7 & 7.33 & 102.7 & 72.0 & 433 & 92 & 4.7 & 1.67 & 0.21 & 6.0 & 5.67 \\
\hline SEM & 1.2 & 3.3 & 1.4 & 3.7 & 1.2 & 60 & 4 & 0.7 & 0.17 & 0.01 & 0.3 & 0.07 \\
\hline$n$ & 3 & 3 & 3 & 3 & 3 & 3 & 3 & 3 & 3 & 3 & 3 & 3 \\
\hline
\end{tabular}

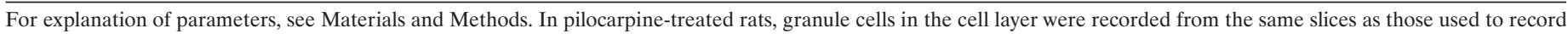

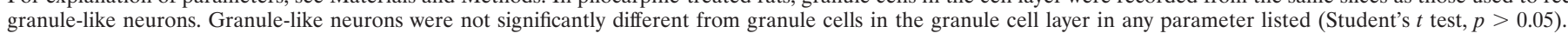

(Gould and Cameron, 1996). Seizure-induced neurogenesis occurs after brief seizures (Bengzon et al., 1997; Nakagawa et al. 2000) or those that are more prolonged, such as pilocarpine- or kainic acid-induced status epilepticus (Parent et al., 1997, 1998; Gray and Sundstrom, 1998; Nakagawa et al., 2000). Kindling also increases granule cell neurogenesis (Parent et al., 1998; Scott et al., 1998). Of particular relevance to our hypothesis was a study by Parent et al. (1997), which used the mitotic marker bromodeoxyuridine (BrdU) to label newly born cells. They showed that some granule cells that are born after seizures can migrate from the subgranular zone into the hilus.

Our results suggest that a large number of newly born granulelike cells can migrate out of the granule cell layer after pilocarpineinduced status epilepticus, and they can migrate quite far from their presumed site of origin, the subgranular zone. The results also suggest functional implications.

Some of the results have been published previously (Scharfman et al., 1999b; Goodman and Scharfman, 1999).

\section{MATERIALS AND METHODS}

Animal care and use met the guidelines set by the National Institutes of Health and the New York State Department of Health. All chemicals were purchased from Sigma (St. Louis, MO) unless otherwise noted.

Pilocarpine and kainic acid treatment. Adult male Sprague Dawley rats (180-240 gm) were injected with either (1) atropine methylbromide $(1 \mathrm{mg} / \mathrm{kg}$, s.c.) and $30 \mathrm{~min}$ later with pilocarpine hydrochloride $(380 \mathrm{mg} / \mathrm{kg}$, i.p.), or (2) kainic acid (12 mg/kg, i.p.). Diazepam ( $5 \mathrm{mg} / \mathrm{kg}$, i.p.; WyethAyerst) was injected after $1 \mathrm{hr}$ of status. The onset of status was defined as the first stage 5 seizure (Racine, 1972) that did not abate after several minutes. After $\sim 5 \mathrm{hr}$, animals were injected with $2.5 \mathrm{ml} 5 \%$ dextrose in lactate-Ringer's solution subcutaneously. For $\sim 7 \mathrm{~d}$, diet was supplemented with apples that were cut open and left at the bottom of the cage. Saline controls were the same age group as drug-treated rats and received identical treatment (atropine, diazepam, and apple), but were injected with saline instead of convulsant. Rats were observed for spontaneous behavioral (motor) seizures (stage 5) at random times between 7:00 A.M. and 8:00 P.M. Observation duration and frequency ranged from $5 \mathrm{~min}(1-5$ times per day) to $3 \mathrm{hr}$ (1-2 times per week).

Hippocampal slice preparation and maintenance. Hippocampal slices (400- $\mu \mathrm{m}$-thick) were prepared from ether-anesthetized rats after decapitation. Slices were cut in ice cold buffer ("sucrose-buffer") containing (in mM): 126 sucrose, $5 \mathrm{KCl}, 2.0 \mathrm{CaCl}_{2}, 2.0 \mathrm{MgSO}_{4}, 26 \mathrm{NaHCO}_{3}, 1.25$ $\mathrm{NaH}_{2} \mathrm{PO}_{4}$, and 10 D-glucose, using a Vibroslice (Campden Instruments). Slices were immediately placed on a nylon net at an interface of sucrose buffer and warm $\left(32-33^{\circ} \mathrm{C}\right)$, humidified $\left(95 \% \mathrm{O}_{2}, 5 \% \mathrm{CO}_{2}\right)$ air using a slice chamber (Fine Science Tools) that was modified in two ways: (1) buffer approached the slices from their undersurface and was directed up and over them and then to a distant exterior port; (2) more air vents were made to allow more humidified air to the area where slices were located. All slices from a given animal were placed in the recording chamber immediately after the dissection. Thirty minutes after slices were placed in the chamber, buffer was switched to one containing $\mathrm{NaCl}$ substituted equimolar for sucrose ("NaCl-buffer"). Recordings began 30 min thereafter until $\sim 7 \mathrm{hr}$ after the dissection. Flow rate was $\sim 1 \mathrm{ml} / \mathrm{min}$.

Electrophysiological recording and analysis. Intracellular and extracellular recordings were made as previously described (Scharfman 1995a,b). Recordings were made with intracellular glass electrodes $(0.75 \mathrm{~mm}$ inner diameter, $1.0 \mathrm{~mm}$ outer diameter) filled with $4 \%$ Neurobiotin (Vector Laboratories, Burlingame, CA) in $1 \mathrm{M}$ potassium acetate $(60-80 \mathrm{M} \Omega)$. Intracellular data were collected using an intracellular amplifier with a bridge circuit (Axoclamp 2B; Axon Instruments, Foster City, CA), and the bridge was balanced whenever current was passed. Extracellular electrodes were filled with $\mathrm{NaCl}$ buffer (5-10 $\mathrm{M} \Omega$ ). Data were collected using a digital oscilloscope (Nicolet Instruments) and analyzed with accompanying software. Data were also digitized and saved on tape (Neurocorder; Neurodata Instruments) for analysis offline.

Cells that were impaled were first screened to ensure that they were healthy (stable resting potential more than $-55 \mathrm{mV}$, overshooting action potential; Table 1). Their intrinsic (membrane) properties were then characterized using intracellularly injected current steps $(0.05-1.5 \mathrm{nA}, 150$ or $500 \mathrm{msec}$ ). Analysis of intrinsic properties was made as previously described (Scharfman 1995a,b). In brief, resting potential was defined as the difference between the potential while intracellular and that recorded after withdrawing the microelectrode from the cell. Input resistance was defined by the steepest slope of an $I-V$ curve based on steady-state responses to a family of current pulses $(0.05-1.0 \mathrm{nA}, 150 \mathrm{msec})$. Time constant was defined as the time to reach $63 \%$ of the steady-state response to a minimal current step $(0.1 \mathrm{nA})$, i.e., one that did not activate rectifying currents. Action potential (AP) characteristics were based on a single AP at threshold evoked by current injected intracellularly (a $0.1-0.5 \mathrm{nA}, 150$ msec pulse) at resting potential. AP "total" amplitude was measured from resting potential to peak, and "threshold" amplitude was from the membrane potential at which the AP started to peak (i.e., between the arrowheads shown in Fig. $6 A$ ). Total AP duration was the time between the start of the AP until the point when it repolarized to the starting membrane potential. Half-width was the period from the start of the AP to the time when the AP reached half of the threshold amplitude. AP maximum rising and decay slopes were defined by the maximum $\mathrm{dv} / \mathrm{dt}$ using a resolution of $50 \mathrm{kHz}$. Dv/dt ratio was defined as the ratio of slope to decay. Afterhyperpolarization (AHP) amplitude was measured from the membrane potential at which the AP started to the peak of the AHP. AHP half-duration was measured from the point when the AHP started to the point when it had decreased to half its peak amplitude. Statistical comparisons were made using Student's $t$ tests (PSI-plot version 4.5; Poly Software International) or $\chi^{2}$ analysis. Significance was set at 0.05 before all experiments.

Intracellular dye injection and processing. Neurobiotin was injected with repetitive depolarizing current pulses (+0.3-1.0 nA, $20 \mathrm{msec}, 30 \mathrm{~Hz}, 5-15$ 

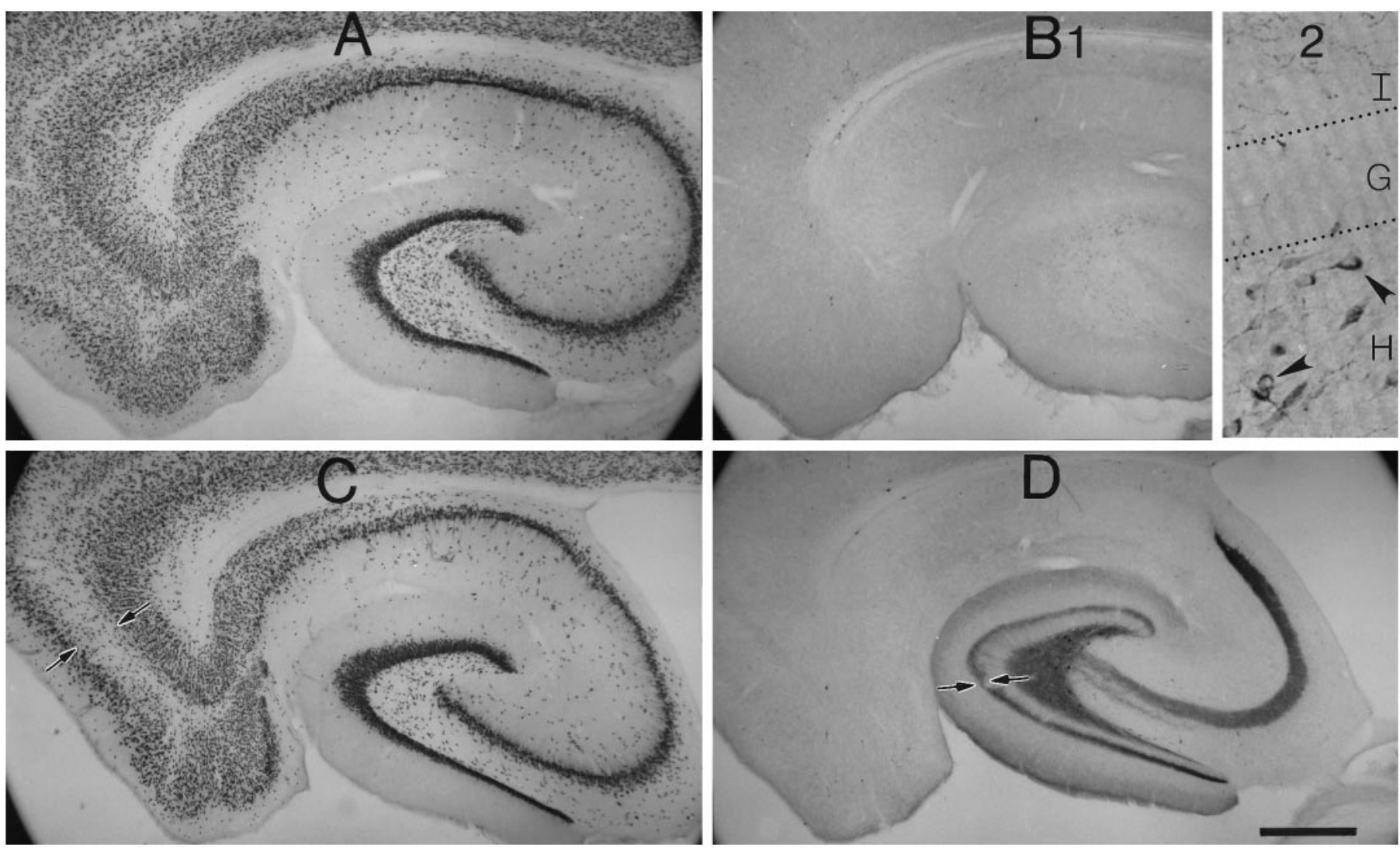

Figure 1. Neuronal loss and mossy fiber sprouting in a kainic acid-treated rat and a saline-injected control. $A$, Immunocytochemistry using an antibody to a neuronal nuclear protein (NeuN) demonstrates neuronal distribution in a saline-treated control rat. $B$, Neuropeptide Y immunoreactivity in an adjacent section to the one shown in $A$ demonstrates numerous immunoreactive cells in the hilar region (arrowheads) and also fibers in the molecular layer. In this and all other figures: $G$, granule cell layer; $H$, hilus; $P$, pyramidal cell layer. $C$, NeuN staining in a section from a kainic acid-treated rat that was perfused 2.75 months after status. There is cell loss in superficial layers of the entorhinal cortex (arrows), but substantial preservation of neurons elsewhere. $D$, Neuropeptide Y staining in an adjacent section to the one shown in $C$ illustrates immunoreactivity in mossy fiber axons of dentate gyrus granule cells, which are unstained in the saline-treated control $(B)$. This example is representative of other rats with spontaneous seizures, where mossy fiber sprouting in the inner molecular layer (arrows) was evident. Scale bar, $500 \mu \mathrm{m}$.

min) after electrophysiological data were collected. Immediately after the experiment, slices were immersed in fixative (4\% paraformaldehyde) and refrigerated for up to 2 weeks. They were resectioned at $50 \mu \mathrm{m}$ using a vibratome (Ted Pella). After incubation overnight in $0.4 \%$ Triton X-100, sections were washed in Tris buffer ( 3 times for 5 min each), incubated in $0.3 \% \mathrm{H}_{2} \mathrm{O}_{2}$ for $45 \mathrm{~min}$, washed, incubated in $\mathrm{ABC}$ (Vector Laboratories) washed, incubated for $20 \mathrm{~min}$ in $0.1 \% \mathrm{NiNH}_{3} \mathrm{SO}_{4}$, followed by $20 \mathrm{~min}$ in diaminobenzidine (Polysciences, Warrington, PA; $50 \mathrm{mg} / 100 \mathrm{ml}$ Tris), washed, dehydrated in a series of graded alcohols (10 min each: 70, 90, and $95 \%$, then $10 \mathrm{~min}$ in $100 \%$ twice), cleared in xylene, and coverslipped in Permount (Fisher Scientific, Pittsburgh, PA). Slides were examined using an Olympus BH-2 light microscope and photographed with $35 \mathrm{~mm}$ camera attachment using Tmax film (100ASA; Eastman Kodak, Rochester, NY).

Histology and immunocytochemistry. Standard procedures for cresyl and Timm stain were used, as previously described (Scharfman et al., 1999a). For immunocytochemistry (Sloviter 1991; Scharfman 1999a), perfusionfixed (4\% paraformaldehyde, $\mathrm{pH} 7.4)$ tissue was sectioned $(50 \mu \mathrm{m})$ with a vibratome (Ted Pella) and processed with an antibody to CaBP (monoclonal, 1:100,000, Sigma or polyclonal, 1:5000, Chemicon, Temecula, CA), calretinin (polyclonal, 1:20,000; Chemicon), Glial fibrillary acidic protein (GFAP; monoclonal, 1:1000; Boehringer Mannheim, Indianapolis, IN), neuropeptide Y (polyclonal, 1:2000; Peninsula), parvalbumin (polyclonal, 1:3000; Swant, Bellinzona, Switzerland), somatostatin (polyclonal, 1:8000; Peninsula), GABA (polyclonal, 1:10,000; Chemicon), glutamic acid decarboxylase (GAD 67; polyclonal, 1:3000; Chemicon), or NeuN (an antibody to a neuronal nuclear protein; monoclonal, 1:5000; Chemicon). For GABA or GAD, fixative contained $2 \%$ paraformaldehyde and $1.5 \%$ glutaraldehyde (Polysciences).

Studies of neurogenesis. Bromodeoxyuridine (BrdU; $50 \mathrm{mg} / \mathrm{kg}$, i.p.; Boehringer Mannheim) was injected twice per day, $\sim 8 \mathrm{hr}$ apart, on days 4-11 and 26-30 after pilocarpine injection. After perfusion with 4\% paraformaldehyde, sections were processed with an antibody to BrdU (monoclonal, 1:1000, Boehringer Mannheim) as described (Parent et al., 1998), using diaminobenzidine as a chromagen and nickel intensification $\left(50 \mathrm{mM} \mathrm{NiCl} l_{2}\right)$. Sections labeled for BrdU were double-labeled for $\mathrm{CaBP}$ and NeuN by incubating with an avidin-biotin blocking solution followed by incubation in primary antibody for $\mathrm{CaBP}$ or NeuN. Visualization of the second marker was made with a water-soluble chromagen that binds to the avidin-biotin peroxidase complex (NovaRed; Vector).

\section{RESULTS}

\section{Sample sizes}

Rats were examined 1-21 months after pilocarpine- $(n=72)$ or kainic acid- $(n=10)$ induced status and compared to 10 agematched saline-treated controls. Of the 72 pilocarpine-treated rats, 49 were dedicated solely to anatomical studies, and the other 23 were studied both physiologically as well as anatomically. The 10 rats treated with kainic acid were only studied anatomically. Of the saline controls, all 10 were studied anatomically, and 4 of the 10 were also studied physiologically. For animals that were studied both physiologically and anatomically, one hemisphere was dedicated for hippocampal slices, and the other hemisphere was immediately fixed by immersion. Anatomical findings from immersionfixed tissue were equivalent to those from perfusion-fixed tissue, so the results from immersion- and perfusion-fixed tissue are pooled.

\section{General behavioral and anatomical observations}

Pilocarpine- and kainic acid-treated rats demonstrated substantial hilar and CA3 neuronal survival (Fig. 1). These rats had spontaneous seizures and mossy fiber sprouting, similar to previous studies of pilocarpine-treated rats that had brief periods of status epilepticus (i.e., 1 hr; Gibbs et al., 1997; Bausch and Chavkin, 1997), or longer periods of status (i.e., over 2 hr; Tauck and Nadler, 1985; Mello et al., 1993; Obenaus et al., 1993; Liu et al., 1994; Okazaki et al., 1995, 1999; Parent et al., 1997; Hellier et al., 1998; Mathern et al., 1998; Motte et al., 1998; Sutula et al., 1998). 

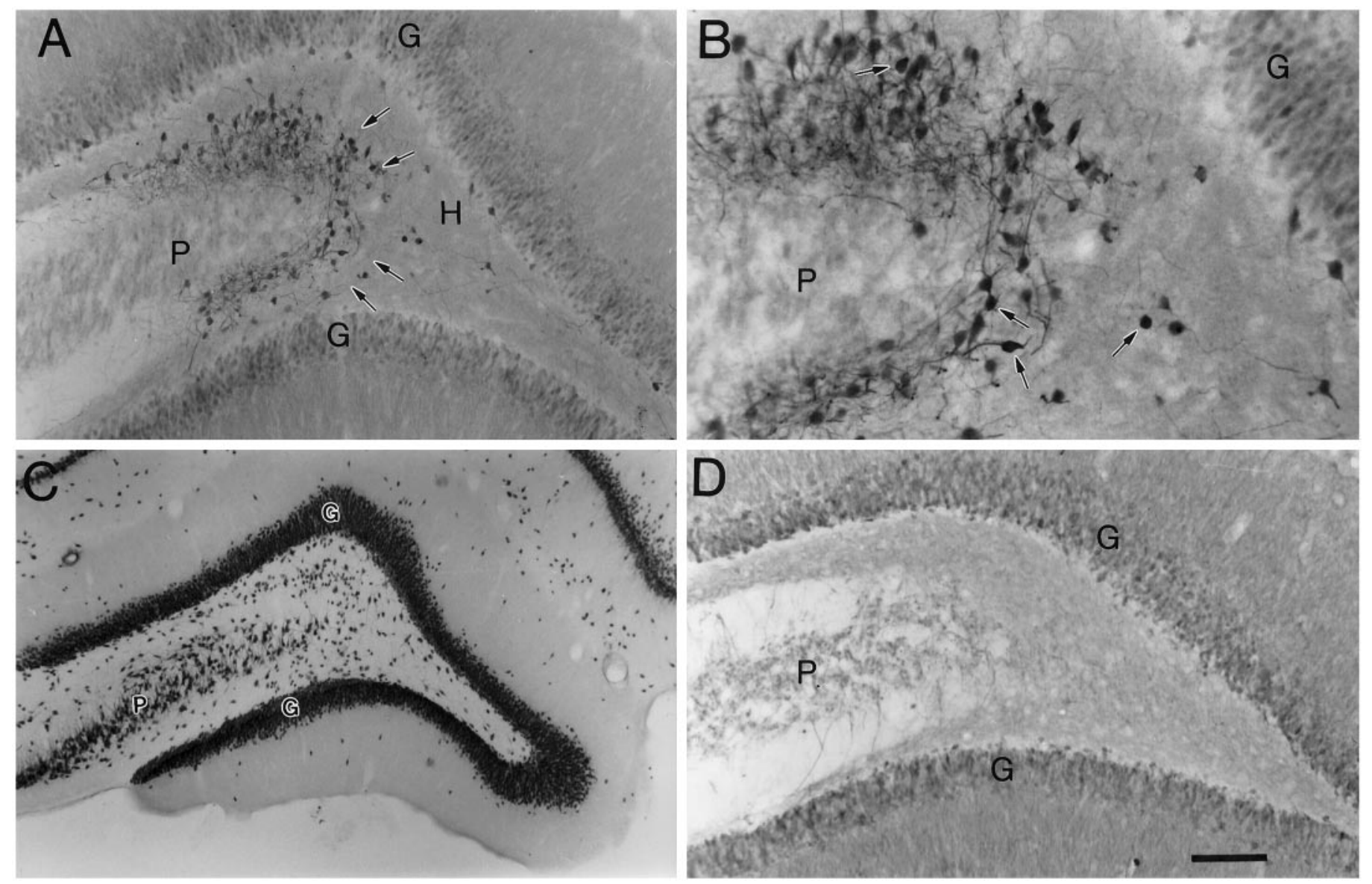

Figure 2. CaBP-immunoreactive cells at the hilar/CA3 border in a kainic acid-treated rat. $A, B, \mathrm{CaBP}$ immunocytochemistry illustrates a population of cells at the hilar/CA3 border that were absent in saline-treated controls $(D)$. $B$ is a higher magnification of $A$. Arrows in $A, B$ point to CaBP-immunoreactive cells. Same animal as shown in Figure 1. $C$, In an adjacent section to the one shown in $A$ and $B$, NeuN staining demonstrate numerous hilar neurons. Scale bar: $A, D, 100 \mu \mathrm{m} ; B, 50 \mu \mathrm{m} ; C, 200 \mu \mathrm{m}$.

Spontaneous limbic seizures (stage 5 of Racine, 1972) were observed in all rats that had convulsant-induced status, except for 9 ( $n=3$ of 72 pilocarpine, $n=6$ of 10 kainic acid). This value is likely to underestimate the number of seizures because the animals were not continuously monitored. In addition, seizures without a behavioral component were not monitored. The frequency of observed stage 5 seizures was $2.47 \pm 0.37$ seizures per month (mean \pm SEM, $n=47$; range, 0.25-14.2) for the pilocarpine group and $0.68 \pm 0.15(n=4$; range, $0.25-1.0)$ for the kainic acid group. Some seizures were greater than stage 5, including wild running and vocalizations.

Anatomical evaluation along the entire septotemporal axis of the hippocampus was conducted in 29 rats after pilocarpine-induced status and recurrent seizures. In these cases, the ventral pole was cut horizontally until reaching the middle of the hippocampus, and then the brain was rotated to section the septal half of the hippocampus in the coronal plane. The horizontal sections facilitated evaluation of the entorhinal cortex, where substantial neuronal loss in the superficial layers was almost always present (28 of 29 rats; $96.5 \%$; Fig. 1). Thinning of the cortex overlying the hippocampus (the perirhinal and temporal cortices) and ventricular enlargement occurred in 18 of 29 rats $(62.1 \%)$. Sprouting in the dentate gyrus, usually evaluated by neuropeptide Y immunoreactivity, was common (i.e., 28 of 29, 96.5\%; Fig. 1). Four of the pilocarpine-treated rats were also examined using Timm stain to mark mossy fibers, and these results demonstrated similar mossy fiber sprouting as shown by neuropeptide Y staining. In the four kainic acid-treated rats with recurrent seizures, all had entorhinal loss and sprouting, but there was no apparent shrinkage of the perirhinal/temporal cortex or ventricular enlargement. Saline-treated controls had no detectable hippocampal or entorhinal cell loss, perirhinal/temporal cortical thinning, ventricular enlargement, or sprouting (Fig. 1).

\section{Calbindin-immunoreactive cells at the hilar/CA3 border in rats with status}

Immunocytochemistry was used to identify characteristics of surviving hilar neurons (Figs. 2-4). CaBP immunocytochemistry showed, surprisingly, a novel plexus of immunoreactive cells at the hilar/CA3 border in rats with recurrent seizures, but not in saline controls (Fig. 2, $A$ vs $D$ ). The hilar/CA3 cells resembled granule cells in their $\mathrm{CaBP}$ immunoreactivity, and also in the small size and oval shape of their somata (Figs. $2 B, 3 D, 10,11$ ). For these reasons and others described below, the hilar/CA3 cells are referred to as "granule-like."

The granule-like cells were present in all rats that were examined throughout the septohippocampal axis $(n=18)$. The borders of the hilus were defined as in Amaral (1978). Two different fixatives and antibodies to $\mathrm{CaBP}$ provided the same results. The plexus was present in animals that were killed within a broad temporal window (1-21 months after status). It was present in animals that had a high frequency of observed seizures as well as those with no observed seizures. Some of the animals with a plexus had mossy fiber sprouting, entorhinal cell loss, and ventricular enlargement (Figs. 1, 4), whereas in other cases these characteristics were absent. Thus, the granule-like $\mathrm{CaBP}$-stained plexus at the hilar/CA3 border was present after two pharmacologically distinct convulsants and appeared to be unrelated to the number of observed spontaneous seizures, survival time after status, or other changes in hippocampal and extrahippocampal structure that might be developing concurrently. 

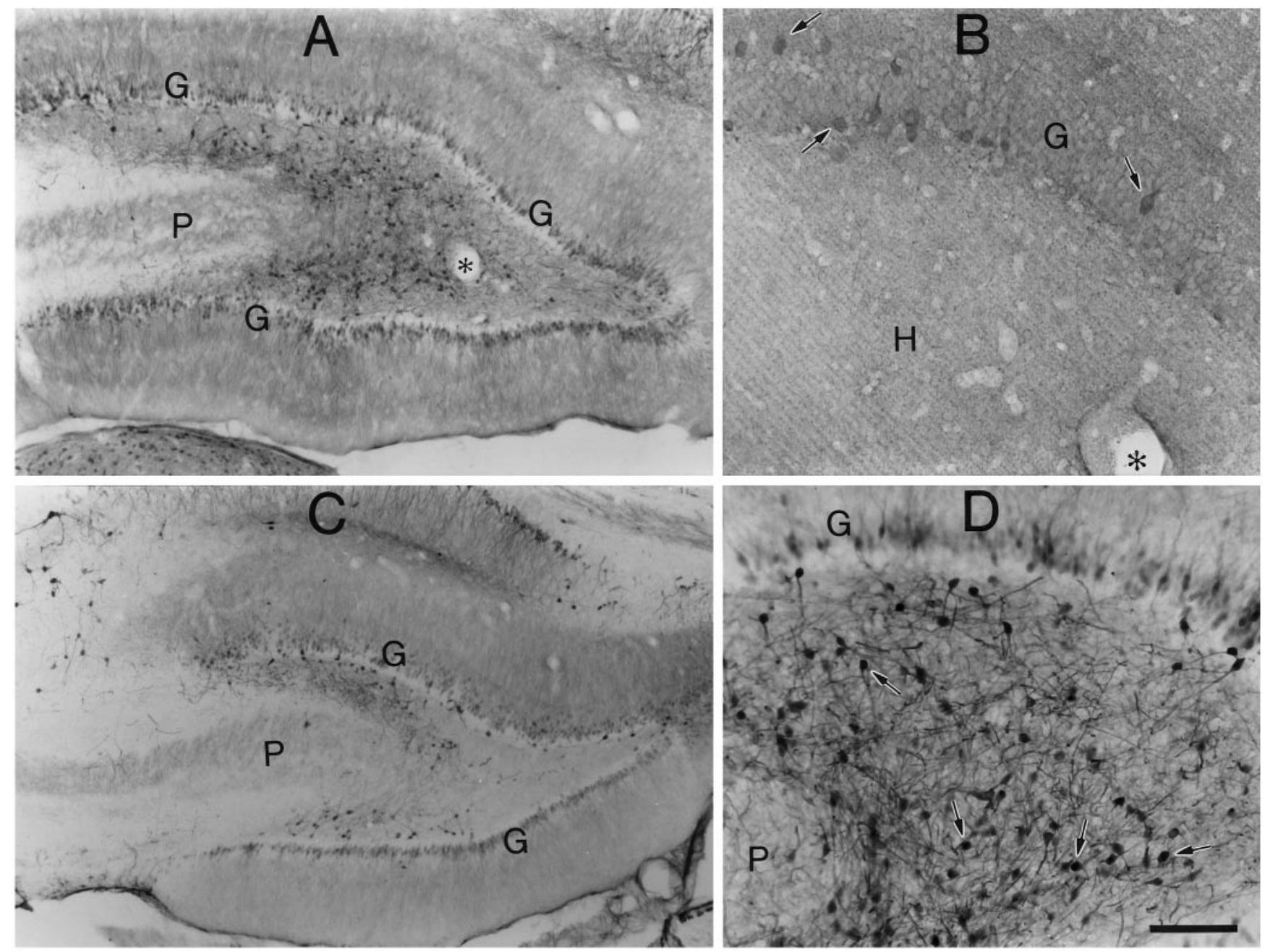

Figure 3. CaBP-immunoreactive neurons were not stained using an antibody to GABA. $A$, CaBP-stained cells in a pilocarpine-treated rat that was examined 10 months after status epilepticus. The asterisk marks a blood vessel that is also marked in $B$. $B$, An adjacent section to the one shown in $A$, stained with an antibody to GABA. Numerous immunoreactive cells are located in and around the granule cell layer (arrows), but not in the hilar region. $C, \mathrm{CaBP}$ immunoreactivity in a section from the septal pole of the same animal. Fewer immunoreactive cells and processes were evident compared to the section from the midhippocampal region $(A)$, an example of variation in $\mathrm{CaBP}$ immunoreactivity along the septotemporal axis of the hippocampus. $D$, Higher magnification of the section in part $A$ showing the CaBP-labeled cells (arrows). Scale bar: $A, C, 250 \mu \mathrm{m} ; B, 100 \mu \mathrm{m} ; D, 50 \mu \mathrm{m}$.

To quantify the CaBP-labeled granule-like cells, $50 \mu \mathrm{m}$ sections were examined at $200-400 \mu \mathrm{m}$ intervals throughout the septal half of the hippocampus in 18 rats with spontaneous seizures $(n=14$ pilocarpine, $n=4$ kainic acid). The septal half was chosen because preliminary studies showed that it contained the most CaBPimmunoreactive hilar neurons. Only tissue that was stained using the same antibody (Sigma) was used. For a given animal, all CaBP-labeled hilar cells were counted in each $50 \mu \mathrm{m}$ section, and the greatest value of CaBP-immunoreactive hilar cells $/ 50 \mu \mathrm{m} \mathrm{sec-}$ tion was then averaged across all animals. Thus, the maximum number of CaBP-labeled cells/50 $\mu \mathrm{m}$ section was $55.4 \pm 7.4(n=$ 18; range, 16-129). For pilocarpine-treated rats, the mean was $55.9 \pm 8.5(n=14 ;$ range, $16-129)$. For the kainic acid group, there were $54.0 \pm 16.8$ cells $(n=4$; range, 23-99). In saline-injected controls that were studied in an analogous manner, the number of CaBP-immunoreactive hilar cells per section was lower $(6.0 \pm 1.48$; $n=5$; range, 1-9; Student's $t$ test, $p<0.05$ ), and none of the CaBP-immunoreactive cells were located at the hilar/CA3 border.

The hilar/CA3 cells could vary in their distribution within the hilar/CA3 area, and in their number from section-to-section along the septotemporal axis. Variation was slight within a range of several hundred micrometers (Fig. 4B,C), but could be substantial over large distances. An example of variation within a single animal is shown in Figure 3. The midhippocampal section had many more CaBP-immunoreactive cells in the hilus than a section from the septal pole of the same animal (Fig. $3 A$ vs $C$ ). The midhippocampal section also showed immunoreactive cells throughout the hilus, whereas in the septal section the cells were clustered at the hilar/CA3 border near the dorsal blade of the dentate gyrus (Fig. $3 A$ vs $C$ ).

\section{Further immunocytochemical analysis of hilar/CA3 granule-like cells}

It was possible that the CaBP-immunoreactive cells at the hilar/ CA3 border were actually a modified GABA neuron or glial cell. To address this possibility, immunocytochemistry was conducted using antibodies to several markers of GABA neurons and a marker of glia. GABA neuron markers included GABA $(n=10$; Fig. $3 B$ ), glutamic acid decarboxylase (GAD67; $n=4$; data not shown), parvalbumin ( $n=7$; Fig. 4), neuropeptide Y $(n=50$; Fig. 4), calretinin ( $n=14$; Fig. 4), and somatostatin ( $n=6$; Fig. 4). GFAP $(n=4$; Fig. 4$)$ was used as a glial marker. Although the granule-like cells at the hilar/CA3 border were labeled by CaBP, there were few or no cells in this area that were stained using markers of GABA neurons or GFAP (Fig. 4). Thus, the hilar/CA3 cells had neurochemical similarities to granule cells because they stained for $\mathrm{CaBP}$, but did not stain like GABAergic interneurons or normal adult glia. They also contrasted with other hilar/CA3 cell types, such as CA3 pyramidal cells and mossy cells, because pyramidal cells and mossy cells are not CaBP-immunoreactive, either 

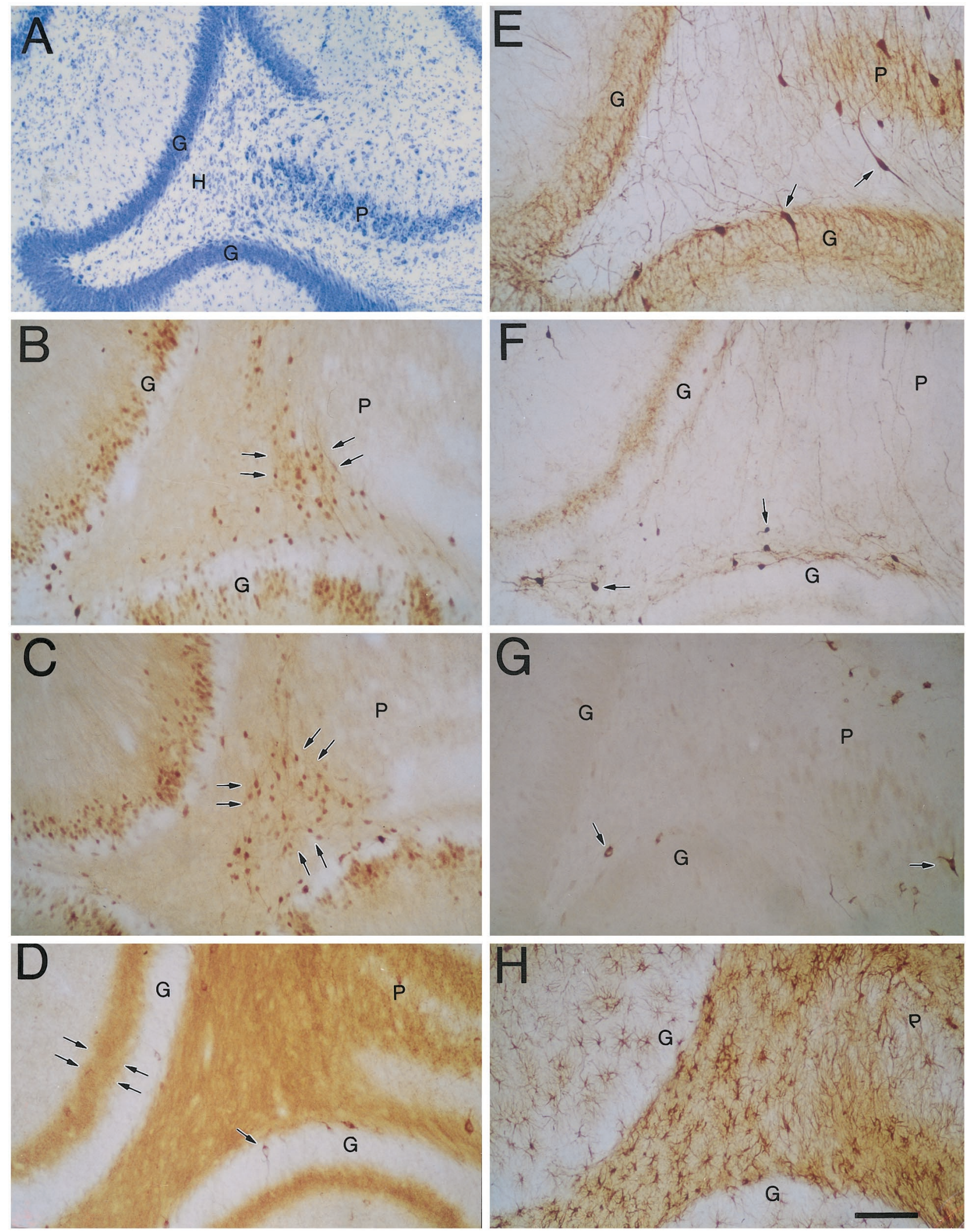

Figure 4. Markers of GABA neurons and glia in the dentate gyrus in a pilocarpine-treated rat with chronic seizures. $A$, Cresyl stain at low power shows relative preservation of neurons in the dentate gyrus of a pilocarpine-treated rat, although other areas of the hippocampus are shrunken. This animal was examined 4 months after status epilepticus and had recurrent motor seizures. In $A-H, \mathrm{CA} 3$ is to the right, and CA1 is up. $B, C$, CaBP immunoreactivity in two different sections from the same animal. $B$ was an adjacent section to the one in $A$, and $C$ was a section from the extreme septal pole of the hippocampus. Immunoreactive neurons in the hilus are marked by arrows. $D$, Neuropeptide $\mathrm{Y}$ immunoreactivity of a section adjacent to $B$ shows mossy fiber sprouting in the inner molecular layer (double arrows) and a few immunoreactive cells in the granule cell layer (arrow), but not the hilus. $E$, $F$ Sequential sections adjacent to $D$ that show immunoreactivity to parvalbumin $(E)$, calretinin $(F)$, somatostatin $(G)$, and GFAP $(H)$. Immunoreactive cells are marked by arrows. Scale bar: $A, 400 \mu \mathrm{m} ; B-H, 100 \mu \mathrm{m}$. 


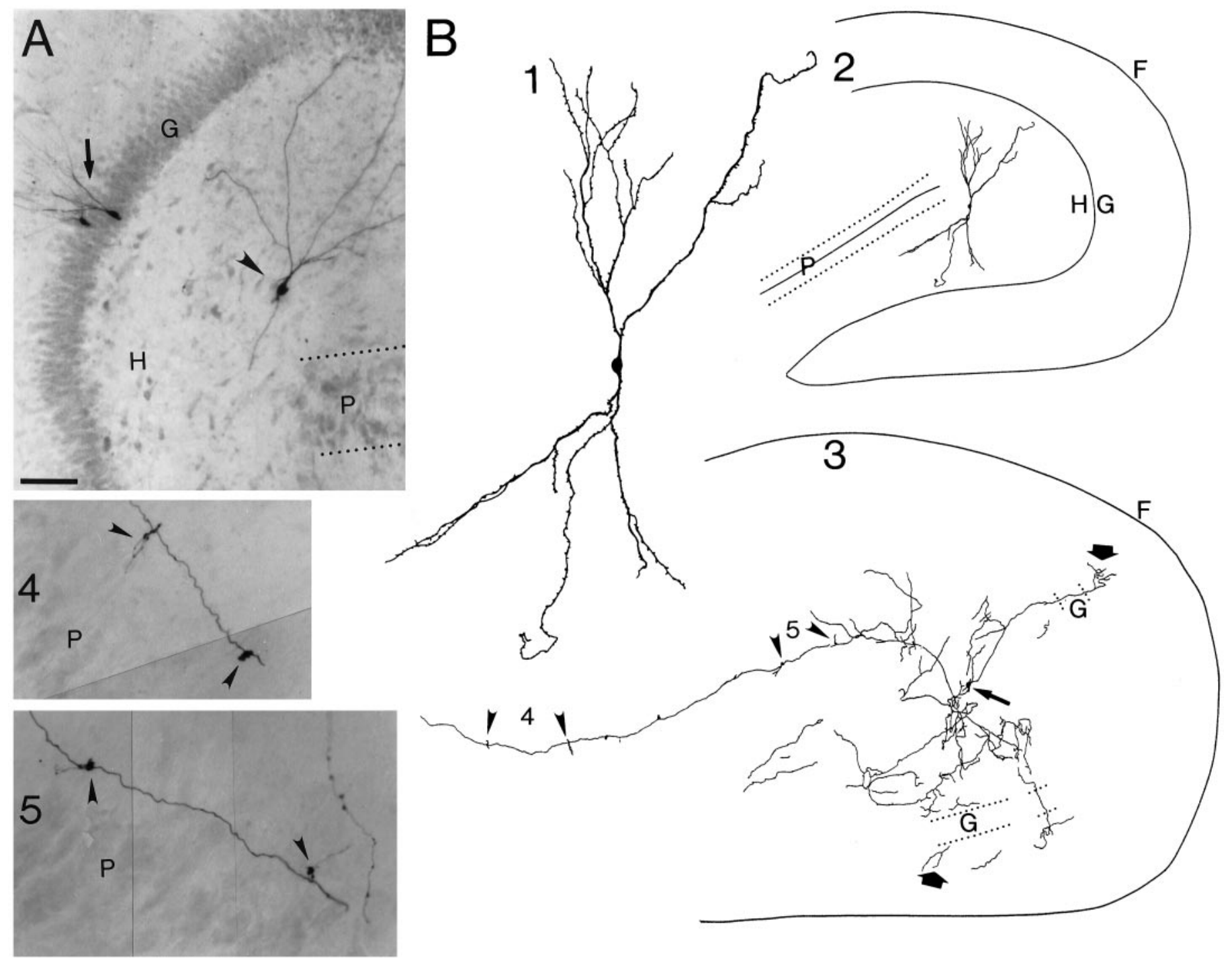

Figure 5. Intracellularly labeled "granule-like" cells in a pilocarpine-treated rat with chronic seizures. A, An intracellularly labeled granule-like cell recorded near the end of the pyramidal cell layer (arrowhead) and granule cells recorded in the granule cell layer (arrow). Orientation: CA3 is to the right, and CA1 is down. B, A different granule-like cell from another slice taken from an animal that had 32 observed seizures in 2.25 months after status. 1, A drawing of the dendrites; 2, orientation of the cell; 3, axon; 4, 5, photomicrographs of mossy fiber boutons along the axon. Dotted lines in 2 and 3 outline the cell layers. Arrowheads in 3-5 point to mossy fiber boutons. Arrow in 3 points to the soma of the cell. Large arrows in 3 indicate areas where axon collaterals were found in the inner molecular layer. The segments shown in 4 and 5 correspond to the areas marked with those numbers in 3 . $F$, Hippocampal fissure. Scale bar: $A, 100 \mu \mathrm{m} ; B 1,50 \mu \mathrm{m} ; B 2,250 \mu \mathrm{m} ; B 3,200 \mu \mathrm{m}$; and B4,5, $25 \mu \mathrm{m}$.

before or after seizures (Figs. 2, 3; Freund et al., 1991; Sloviter, 1989; Seress et al., 1993; Shetty and Turner, 1995).

\section{Hippocampal slice electrophysiology and intracellular labeling}

To determine the morphological and physiological characteristics of neurons at the hilar/CA3 border, neurons in this location were recorded intracellularly in slices from pilocarpine-treated animals that had status and subsequent spontaneous seizures (referred to below as the pilocarpine group, $n=55$ slices from 23 rats). All slices from a given animal were placed in the recording chamber at the same time so that they would be exposed to the same conditions. Four saline-treated controls (14 slices) and four pilocarpinetreated animals that did not have status or subsequent spontaneous seizures (10 slices), were examined in an analogous manner. Data from the last two groups did not show differences, so they are pooled below and referred to as controls.

Neurons from the hilar/CA3 border were recorded (pilocarpine, $n=62$; controls, $n=14$ ), as well as granule cells in the granule cell layer (pilocarpine, $n=68$; controls, $n=26$ ). In control rats, granule cells located 50-100 $\mu \mathrm{m}$ from the granule cell layer were used for additional comparisons ("ectopic" granule cells; $n=6$; Gaarskjaer and Laurberg, 1983; Table 1).

\section{Morphology of granule-like neurons at the hilar/CA3 border}

In the pilocarpine group, many neurons at the hilar/CA3 border had, surprisingly, the characteristics of normal adult granule cells in the granule cell layer. No cells with granule-like characteristics were found at the hilar/CA3 border in control tissue.

Twenty-one hilar/CA3 neurons from the pilocarpine group were recorded that had granule cell-like intrinsic properties (see below), and 12 were filled with Neurobiotin. All cells had small, oval cell bodies and spiny dendrites, like granule cells (Fig. 5). There were no thorny excrescences, also like granule cells. Three had a polarized dendritic tree, like a normal adult granule cell (i.e., dendrites arising from one side of the cell body; Fig. $5 A$ ). Other cells were bipolar, having dendrites emerging from opposite sides of the cell body (Fig. $5 B$ ). The bipolar cells resembled granule cells after seizures with "basal" dendrites (Spigelman et al., 1998; Buckmaster and Dudek, 1999).

An extensive axon was labeled in three granule-like cells, and mossy fiber boutons were evident in the hilar region and in stratum 


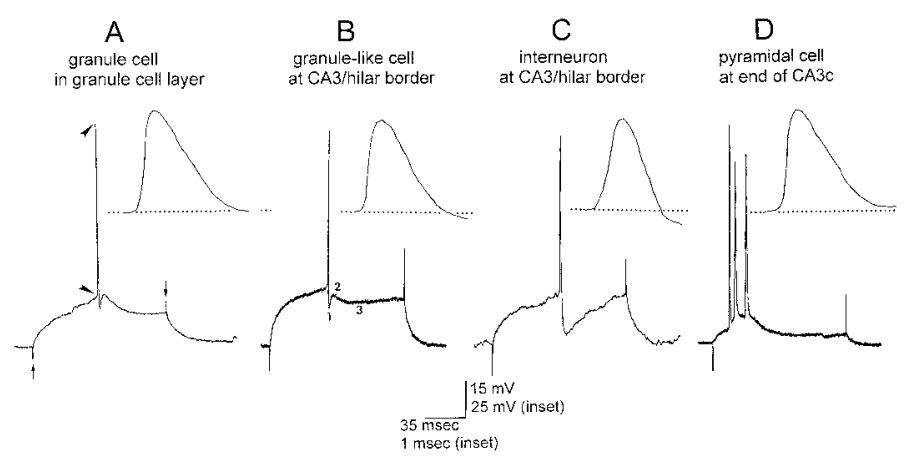

Figure 6. APs of neurons recorded at the hilar/CA3 border in pilocarpinetreated rats with chronic seizures. $A$, An AP evoked at threshold by intracellularly injected current $(150 \mathrm{msec}$ pulse). The start and end of the pulse are marked by small arrows. The recording was from a granule cell in the granule cell layer in a pilocarpine-treated rat that was examined 4.5 months after status. Inset, The AP is shown with a different scale to illustrate the relatively fast rise and slow decay of granule cell APs compared to interneurons $(C)$. Resting potential, $-70 \mathrm{mV}$. $B$, An AP from a granule-like cell at the hilar/CA3 border in a different pilocarpine-treated rat that was killed 1 month after status. Note the similarity of the AHP in $A$ and $B$. The three phases of the AHP are indicated by numerals at the peak of each phase. Resting potential, $-73 \mathrm{mV}$. C, An AP from a hilar/CA3 neuron with the morphology and physiological characteristics of a GABA neuron ("interneuron"). Same slice as used for part $A$. The AHP differs from granule cell AHPs in both amplitude and kinetics. Resting potential, $-65 \mathrm{mV} . D$, A triplet of APs evoked at threshold in a CA3c pyramidal cell at the hilar border in a pilocarpine-treated rat, 9 months after status. Intrinsic bursts of APs are characteristic of these cells (Wong and Prince, 1981; Scharfman, 1993; Smith et al., 1995). Resting potential, $-60 \mathrm{mV}$.

lucidum of area CA3 (Fig. $5 B$ ). Figure $5 B 3$ shows an example in which the major branch of the axon could be traced from the hilus to area CA3b. There were periodic mossy fiber boutons, and some had filamentous extensions, as has been described for classic mossy fiber boutons of normal adult granule cells of the granule cell layer (Fig. 5B4-B5; Blackstad and Kjaerheim, 1961; Hamlyn, 1962; Claiborne et al., 1986; Frotscher, 1985, 1989; Chicurel and Harris, 1992; Acsády et al., 1998). Axons of two of the three neurons also had collaterals in the inner molecular layer (Fig. 5B3). The inner molecular layer axon collaterals suggest that granule-like cells can contribute to mossy fiber sprouting (but see Parent et al., 1999).

\section{Electrophysiological characteristics of granule-like cells at the hilar/CA3 border}

As shown in Table 1, the membrane properties of granule-like cells at the hilar/CA3 border could not be distinguished from granule cells that were located in the granule cell layer in the same slices. Membrane properties also were similar to normal adult granule cells recorded from saline controls or "ectopic" granule cells in normal rats (i.e., granule cells that were located 50-100 $\mu \mathrm{m}$ from the granule cell layer/hilar border; Table 1).

Other types of cells at the hilar/CA3 border were distinct from granule-like cells. In both control and epileptic tissue, cells with morphological and physiological similarities to interneurons or CA3c pyramidal cells were encountered at the hilar/CA3 border (Figs. 6-7; interneurons: $n=10$ pilocarpine, $n=2$ control; pyramidal cells: $n=26$ pilocarpine, $n=6$ control). Hilar mossy cells were not encountered at the hilar/CA3 border, but were recorded in the areas closer to the granule cell layer (data not shown).

APs of granule-like hilar/CA3 neurons and granule cells located in the granule cell layer were similar (Fig. 6), and were unlike the APs of interneurons and CA3c pyramidal cells. Single APs (evoked at threshold by injected current, see Materials and Methods) of granule cells and granule-like cells were characterized by a relatively fast rising phase and slow decay, and a triphasic AHP (Fig. 6, Table 1), as has been described for granule cells in normal tissue (Scharfman, 1992, 1995a; Spruston and Johnston, 1992; Staley et al., 1992; Williamson et al., 1993; Mott et al., 1997; Lübke et al., 1998). Interneuron APs were characterized by relatively similar AP rising and decay slopes (i.e., a dv/dt ratio closer to 1.0; Table 1), and a large, rapid AHP, as previously described (Fig. 6; Lacaille et al., 1989; Scharfman, 1992, 1993, 1995a; Buhl et al., 1994; Buckmaster and Schwartzkroin, 1995; Smith et al., 1995; Freund and Buzsáki, 1996; Mott et al., 1997; Lübke et al., 1998; Parra et al., 1998). CA3c pyramidal cell firing behavior at threshold demonstrated intrinsic bursts of three or four APs, as has been demonstrated in past studies of these neurons in normal tissue (Fig. 6; Wong and Prince, 1981; Scharfman, 1993; Smith et al., 1995). Pyramidal cell AP
A

granule cell in granule cell layer
B granule-like cell at CA3/hilar border

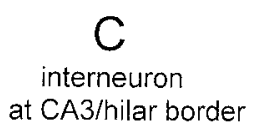

pyramidal cell
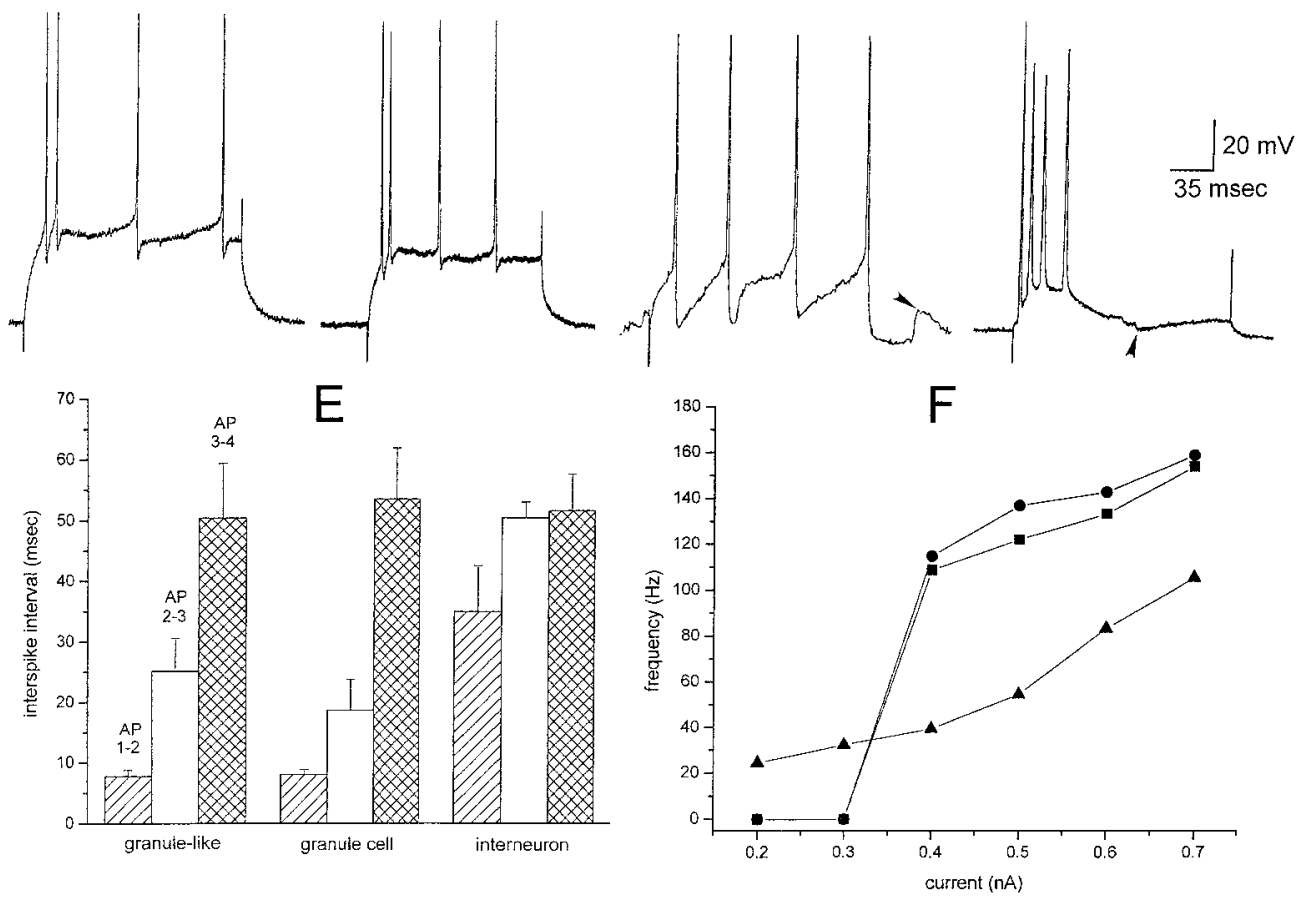

Figure 7. Firing behavior of neurons at the hilar/CA3 border. Responses to current injection were recorded from the same cells shown in Figure 6. The amount of injected current was manipulated so that each neuron fired four APs within $150 \mathrm{msec}$. $A, B$, Firing behavior of a granule cell in the granule cell layer $(A)$ and a granule-like cell at the hilar/CA3 border (B) were similar in that trains of APs occurred with strong spike frequency adaptation. $A$, Resting potential, $-71 \mathrm{mV}$. $B$, Same cell as Figure $6 B$. $C$, Firing behavior of an interneuron demonstrated weak spike frequency adaptation. Same cell as Figure $6 C . D$, A CA3c pyramidal cell had an intrinsic burst of APs in response to injected current. Same cell as Figure $6 D$. The arrowheads in $C$ and $D$ point to spontaneous synaptic potentials, depolarizing in $C$ and hyperpolarizing in $D$. E, Comparison of the mean ( \pm SEM) interspike intervals of the train of four APs are compared for the three cell types firing in trains (granule cells, granule-like cells, and interneurons). $F$, An $f-I$ plot for the same group of cells as in part $E$. The mean value of the first interspike interval is plotted as a function of injected current. 

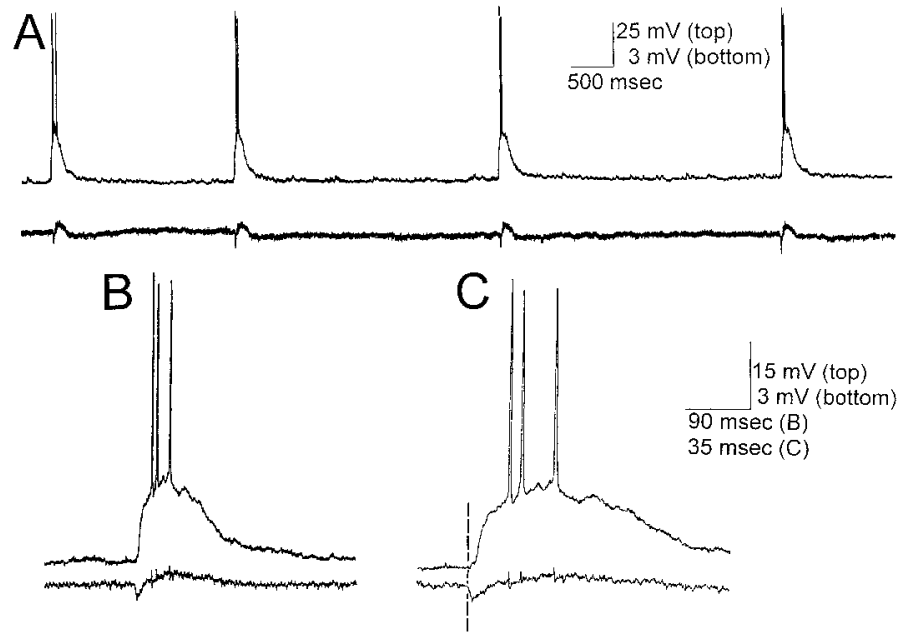

Figure 8. Simultaneous bursts recorded from granule-like cells intracellularly and the CA3 pyramidal cell layer extracellularly. $A$, Recordings of spontaneous activity from a granule-like cell (top; same cell as shown in Fig. $5 B)$ and a simultaneous recording from the CA3b pyramidal cell layer (bottom) show spontaneous bursts that were periodic and synchronized. Resting potential, $-74 \mathrm{mV} . B, C$, A sample record of one burst with different time bases illustrates the onset of APs in the granule-like cell, and the onset of population spikes in the CA3b field were tightly synchronized.

slopes were similar to granule cells, but there was no appreciable fast AHP (Fig. 6; Wong and Prince, 1981; Scharfman, 1993; Smith et al., 1995).

In granule cells and granule-like neurons, multiple APs (evoked by currents more than threshold, injected intracellularly) occurred in trains with strong spike frequency adaptation. Strong spike
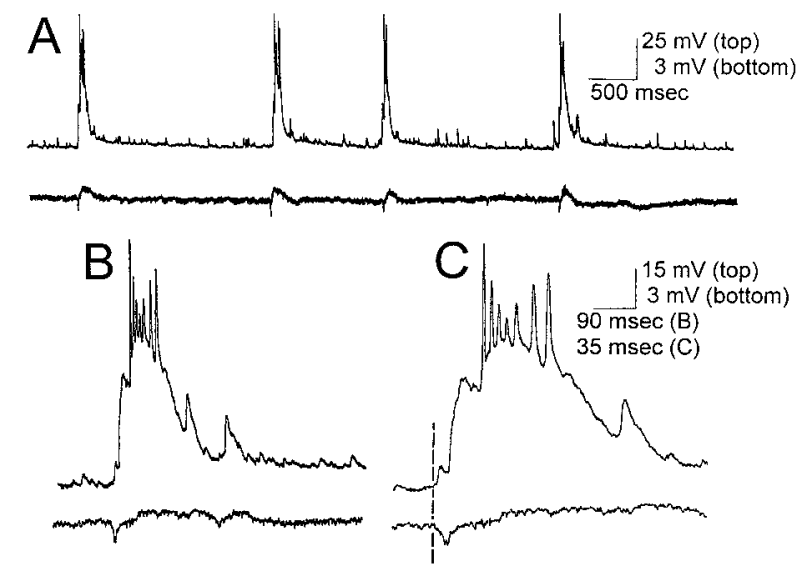

Figure 9. Simultaneous bursts recorded simultaneously in a CA3c pyramidal cell and CA3b of the pyramidal cell layer. $A$, Recordings in the same slice as used for Figure 8, showing simultaneous bursts in a CA3c pyramidal cell (top; resting potential, $-58 \mathrm{mV}$ ) and the CA3b pyramidal cell layer. $B, C$, Expanded traces of a burst recorded simultaneously in the pyramidal cell (top) and pyramidal cell layer (bottom) show that the bursts begin at similar times.

frequency adaptation has been described previously as a characteristic of normal adult granule cells (Scharfman, 1992; Williamson et al., 1993; Mott et al., 1997). Adaptation was quantified in two ways: (1) by analyzing the first three interspike intervals of a train with exactly four APs in $150 \mathrm{msec}$ (Fig. $7 E$; the amount of injected current was manipulated so that exactly four APs were evoked in each cell), and (2) by analyzing the first interstimulus interval as a function of injected current $(f-I$ curves; Fig. $7 F)$. Both interspike interval and $f-I$ curves yielded comparable values between granule-
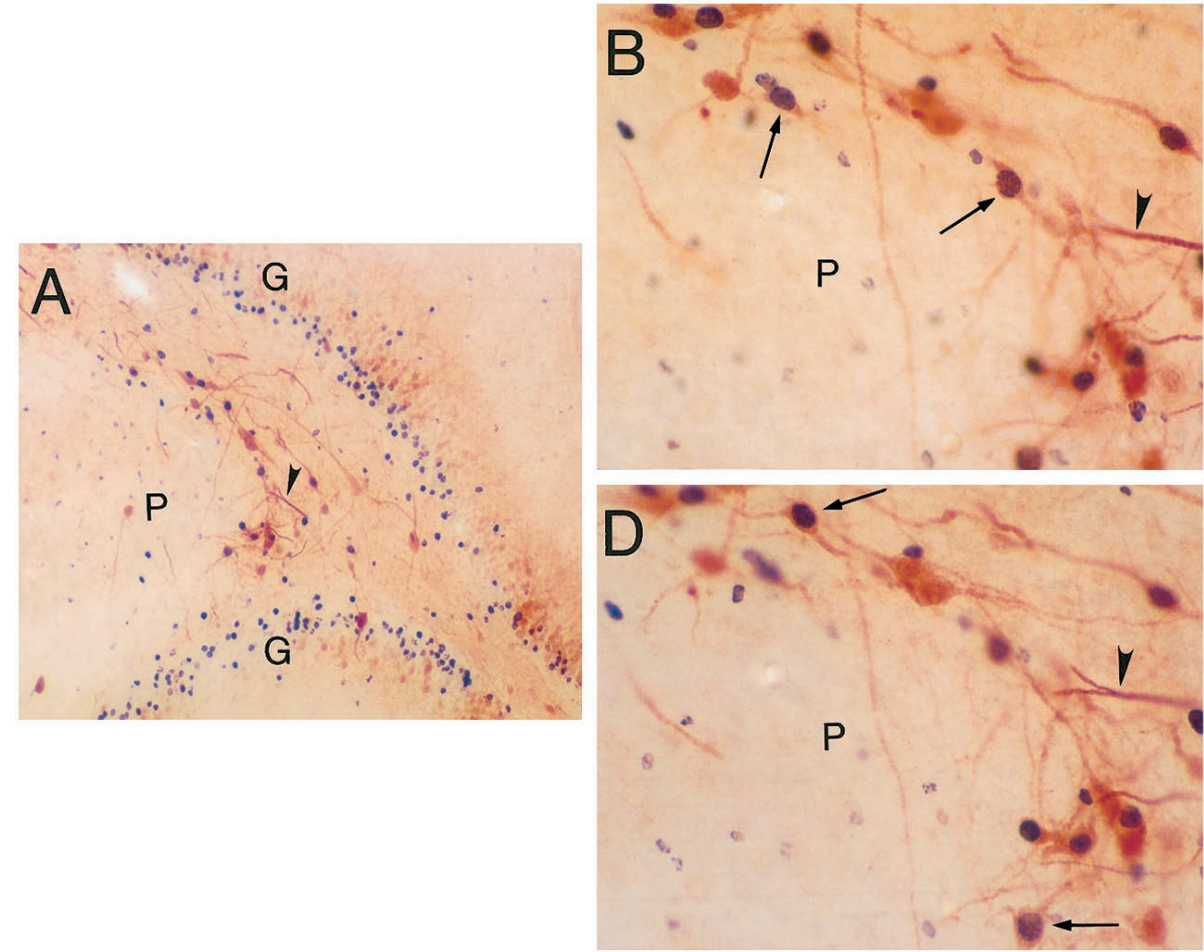
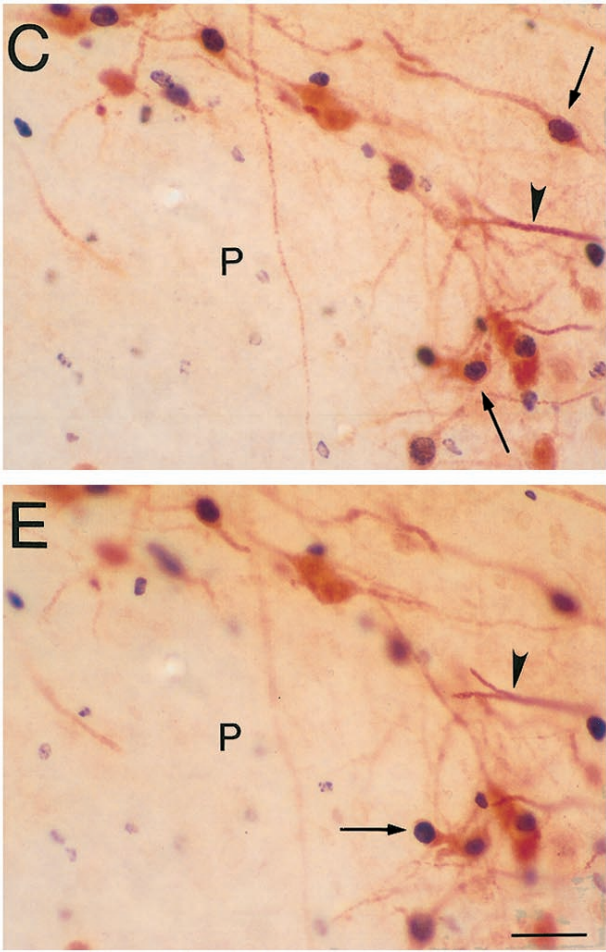

Figure 10. Newly born CaBP-stained neurons at the hilar/CA3 border in pilocarpine-treated rats with spontaneous seizures. In a pilocarpine-treated rat 2.5 months after status, CaBP-stained hilar/CA3 neurons were often double-labeled with an antibody to BrdU. BrdU was injected 4-11 and $26-30 \mathrm{~d}$ after status epilepticus (see Materials and Methods). A, The hilar/CA3 border had numerous double-stained cells (i.e., CaBP-positive/BrdU-positive). Numerous BrdU-labeled cells were also located in the subgranular zone. Arrowhead in $A$ points to the same CaBP-positive branched process that is marked by an arrowhead in $B$. Scale bar (in $E$ ), $100 \mu \mathrm{m} . B-E$, The hilar/CA3 border near the arrowhead in $A$ is shown at higher power. Double-stained cells are marked by arrows. Several focal planes are shown to illustrate that the CaBP-positive cytoplasm and BrdU-positive nucleus go in and out of focus together. This indicates true double-labeling, as opposed to juxtaposed cells, such as a CaBP-positive, BrdU-negative cell lying under a BrdU-positive, CaBP-negative cell. Scale bar, $50 \mu \mathrm{m}$. 


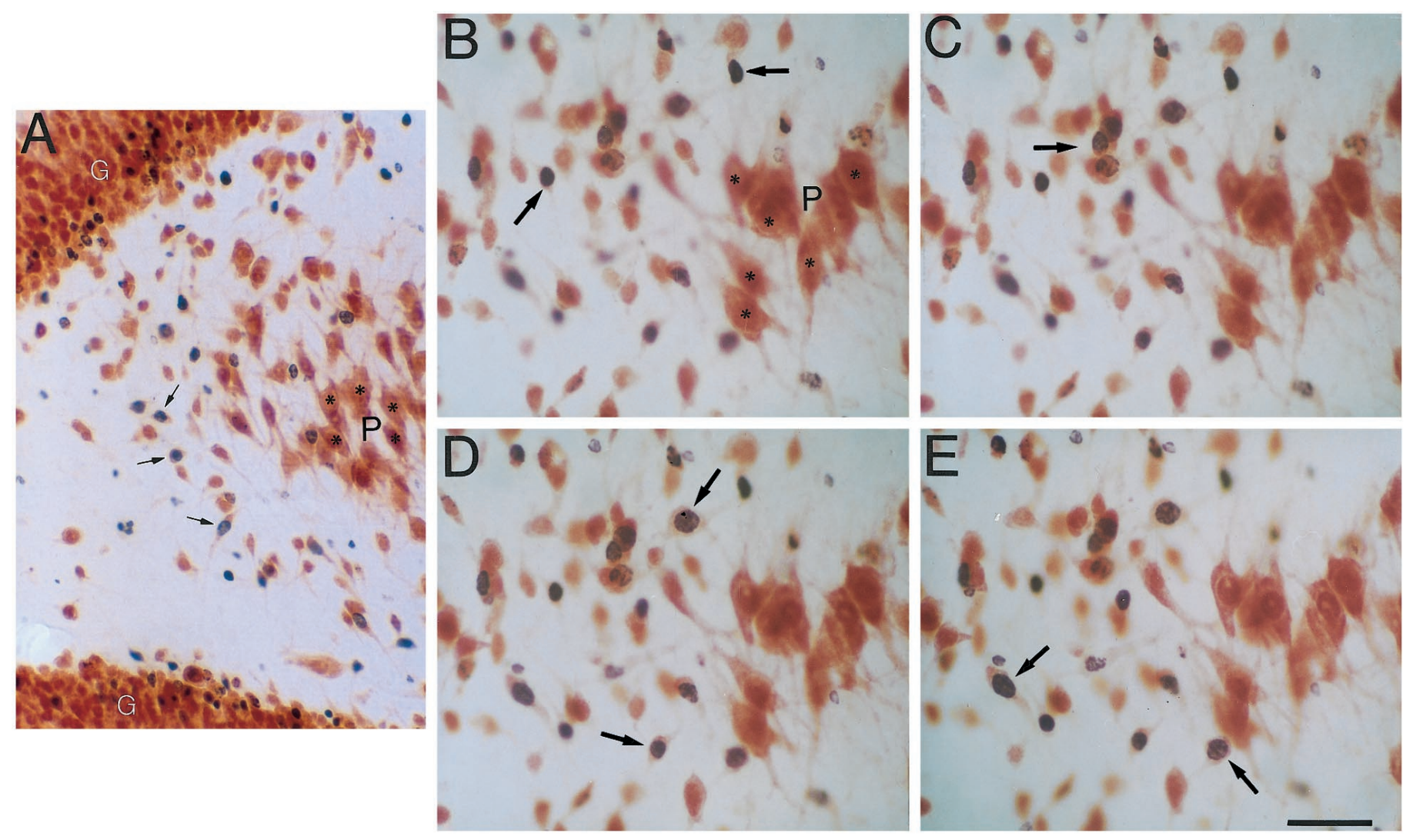

Figure 11. NeuN-stained neurons at the hilar/CA3 border in pilocarpine-treated rats with spontaneous seizures. $A$, The hilar/CA3 border stained for NeuN and BrdU. Same animal as Figure 10. Numerous double-labeled cells (NeuN-positive/BrdU-positive) are located in this area (arrows), as well as the base of the granule cell layer. Asterisks in $A$ and $B$ mark CA3c pyramidal cells. Scale bar (in $E$ ), $100 \mu \mathrm{m}$. $B-E$, A focal series through the hilar/CA3 border, showing numerous NeuN-labeled cells also are labeled by BrdU (arrows). Different animal from $A$. Nine seizures were observed in this rat in the 2.25 months between status and perfusion-fixation. Scale bar, $50 \mu \mathrm{m}$.

like cells and granule cells located in the cell layer (Fig. 7A,B,E,F). However, hilar interneurons recorded in the same slices were quite different, as has been described in normal rats (Fig. 7C; Scharfman, 1992, 1995; Buckmaster and Schwartzkroin, 1995; Mott et al., 1997; Lübke et al., 1998). Thus, the $f-I$ curve of interneurons had a shallow slope compared to granule cells and granule-like cells (Fig. $7 F$ ). Relatively weak adaptation of interneurons was evident in the similarity of interspike intervals within a train of four APs (Fig. $7 C, E)$. CA3c pyramidal cells were also different from granule cells and granule-like cells in that intrinsic bursts of APs were evoked rather than trains of adapting APs, as has been described in normal rats (Fig. 7D; Wong and Prince, 1981; Scharfman, 1993; Smith et al., 1995). Thus, in membrane properties and firing behavior, granule-like cells were similar to granule cells and distinct from interneurons and pyramidal cells.

\section{Spontaneous epileptiform bursts in area CA3 of slices}

Interestingly, there were abnormalities in the CA3 region in slices from pilocarpine-treated rats with spontaneous seizures, in addition to abnormalities at the hilar/CA3 border. CA3 pyramidal cells often had periodic spontaneous bursts of APs riding on large depolarizations (presumably EPSPs). Furthermore, all granule-like cells impaled in slices with CA3 population bursts $(n=16)$ had bursts of APs that were synchronous with CA3 (Fig. 8). The CA3 bursts resembled those that occur in normal rat hippocampal slices exposed to convulsants (Wong and Traub, 1983; Swann and Brady, 1984; Ault et al., 1986; Chestnut and Swann, 1988; Müller and Misgeld, 1991; Perreault and Avoli, 1991), including pilocarpine (Nagao et al., 1994; Rutecki and Yang, 1998) or animal models of epilepsy (Lee et al., 1995b; Smith et al., 1998).

CA3 spontaneous population bursts were $75-500 \mathrm{msec}$ in length, occurred at a $0.1-0.33 \mathrm{~Hz}$, and only occurred in animals that had spontaneous seizures. Bursts could be recorded extracellularly, but this was difficult because population spikes within each burst were only 1-2 $\mathrm{mV}$ in amplitude (Figs. 8-9), much less than population spikes recorded using normal slices, similar recording conditions, and exposed to convulsants (Scharfman, 1994).

CA3 epileptiform bursts were recorded preferentially in animals that were examined at least 5 months after status. Thus, in the 18 rats in which extracellular recordings were made over 5 months after status, $90 \%$ (19 of 21 slices; $n=9$ rats) of slices had spontaneous activity in at least one of the 3 CA3 subfields (i.e., a, b, and c). For tissue $<5$ months after status, $47 \%$ of slices (15 of 32; $n=9$ rats) demonstrated spontaneous CA3 bursts, which was significantly different $\left(\chi^{2}\right.$ analysis, $\left.\chi^{2}=10.38\right)$.

All CA3 pyramidal cells that were recorded intracellularly had bursts of APs that were synchronous with bursts recorded extracellularly from the CA3 cell layer $(n=20)$, but CA3 cells did not burst if there was no extracellularly recorded CA3 burst $(n=6)$ or in saline controls $(n=6)$. Figure 9 shows a simultaneous extracellular recording from the CA3b pyramidal cell layer and an intracellular recording from a CA3c pyramidal cell. These records illustrate synchronous spontaneous bursts in pyramidal cells of areas CA3c and CA3b. Field potentials in CA3a and CA3c were usually smaller than those in CA3b, and in some cases could not be detected, even when epileptiform bursts were recorded extracellularly in CA3b. However, in those cases, CA3 a or c neurons had bursts that were synchronized with the CA3b population burst recorded extracellularly.

The onset of bursts in granule-like cells relative to the onset of the CA3 population burst (defined as the onset of the first population spike within a burst) varied. In some cases bursts of APs in granule-like cells sometimes began at the onset of the population burst in CA3 (Fig. 8). This suggests tight synchrony. However, in other slices the bursts of granule-like cells could occur up to 48 
msec after the onset of CA3 population bursts. The onset of bursts in pyramidal cells also varied relative to the onset of the CA3 population burst. Pyramidal cell bursts could start up to $10 \mathrm{msec}$ before, or up to $55 \mathrm{msec}$ after the onset of the population event in CA3b. However, despite variability among different neurons, a given cell maintained a relatively fixed latency relative to the onset of the CA3 population burst.

\section{Are granule-like hilar/CA3 neurons newly born granule cells?}

Given the similarity of the cells at the hilar/CA3 border to granule cells immunocytochemically (i.e., immunoreactive for $\mathrm{CaBP}$ but not parvalbumin, somatostatin, calretinin, etc.), morphologically (i.e., small soma, spiny dendrites, mossy fiber axon), and electrophysiologically (membrane properties, firing behavior), and given the evidence that granule cells born after seizures migrate into the hilar region (Parent et al., 1997), we hypothesized that the CaBPlabeled cells at the hilar/CA3 border were granule cells that were born after status and migrated abnormally to the hilar/CA3 border.

To address this hypothesis, three pilocarpine-treated rats and two saline controls were injected with BrdU (after pilocarpine or saline injection) and were examined several weeks later. Doublelabeling of neurons at the hilar/CA3 border was apparent in all pilocarpine-treated animals, but not in saline-treated controls. Figure 10 shows double-labeling of $\mathrm{CaBP}$ - and BrdU-immunoreactive cells at the hilar/CA3 border from one of the pilocarpine-treated animals with recurrent seizures, examined 4 weeks after BrdU injections stopped. Figure 11 shows BrdU-labeled cells were also immunoreactive for NeuN, and therefore are likely to be neurons rather than glia. These data are consistent with the CaBP-positive nature of newly born granule cells in adult rats described elsewhere (Markakis and Gage, 1999). Thus, cells at the hilar/CA3 border included newly born cells with granule cell characteristics. Importantly, other types of cells at the hilar/CA3 border may also be newly born.

The number of $\mathrm{CaBP} / \mathrm{BrdU}$ - or NeuN/BrdU-immunoreactive neurons we observed does not necessarily reflect the number that were newly born. BrdU labeling is likely to underestimate the number of newly born cells, given that BrdU was only administered for a short period, and granule cells could have been born at many other times, i.e., whenever animals had spontaneous seizures. Furthermore, $\mathrm{CaBP}$ immunoreactivity is not present in immature granule cells (Rami et al., 1987; Goodman et al., 1993), and some of the newly born cells could have been immature at the time of perfusion-fixation. CaBP expression also decreases in adult granule cells after seizures (Baimbridge and Miller, 1984; Baimbridge et al., 1985; Shetty and Turner, 1995; Sloviter et al., 1991; Yang et al., 1997; Nagerl et al. 2000) (but see Lowenstein et al., 1991).

\section{DISCUSSION}

In summary, a novel population of granule-like neurons has been demonstrated in the hippocampus in two animal models of epilepsy. The granule-like neurons were similar morphologically, electrophysiologically, and neurochemically to the granule cells in the granule cell layer. Results of BrdU-labeling experiments were consistent with the hypothesis that the granule-like cells represent granule cells that were born after status and migrated incorrectly to the hilar/CA3 border. In addition, it was shown that the granulelike neurons had spontaneous, regular epileptiform bursts that were synchronized with area CA3 pyramidal cells. Epileptiform activity occurred preferentially in animals that had been examined long after status. The epileptiform bursts of newly born granule-like cells and CA3 pyramidal cells suggest new mechanisms that could contribute to abnormal excitability.

\section{Comparison of granule-like neurons and normal adult granule cells in the granule cell layer}

Granule cells in the granule cell layer and granule-like neurons were similar in several ways. They were similar in the morphology because they had small, oval somata, mossy fiber axons with giant boutons, spines on dendrites, and lacked thorny excrescences. They were similar in immunoreactivity to $\mathrm{CaBP}$, but not somatostatin, parvalbumin, or calretinin. They were similar to granule cells in pilocarpine-treated rats with mossy fiber sprouting because they had axon collaterals in the inner molecular layer. To our knowledge, there is no other hippocampal cell type besides granule cells that has all of these characteristics.

Similarities were also apparent physiologically. Membrane properties and firing behavior of granule-like cells were similar to normal granule cells (e.g., high resting potential, triphasic AHP, and strong spike frequency adaptation). The characteristics were distinct from other cell types in the hilar/CA3 region, such as interneurons and CA3 pyramidal cells. They were also unlike mossy cells in normal rats (Scharfman and Schwartzkroin, 1988; Scharfman, 1999).

Granule-like cells differed from normal granule cells in three ways. First, granule-like cells were not immunoreactive using antibodies to GABA or GAD. This is a characteristic of granule cells located in the cell layer, particularly in the time just after seizures (Sandler and Smith, 1991; Schwarzer and Sperk, 1995; Sloviter et al., 1996; Makiura et al., 1999). However, neither the granule cells in the granule cell layer nor the granule-like cells at the hilar/CA3 border appeared to be strongly immunoreactive in our tissue. One reason might be that the animals that were examined did not have a recent behavioral seizure.

Second, neuropeptide $\mathrm{Y}$ is also expressed in granule cells after seizures (Sperk et al., 1992, 1996; Lurton and Cavalheiro, 1997), but was not a characteristic of granule-like neurons (i.e., there was no evidence of small, oval neuropeptide Y-immunoreactive somata at the hilar/CA3 border). However, there could have been axon terminal expression; this could not be evaluated because the locations of axon terminals of granule-like cells overlap the sites of terminals of other neurons that express neuropeptide $\mathrm{Y}$ (e.g., granule cells, interneurons).

Third, most granule-like cells had bipolar dendritic trees rather than polarized dendrites, the latter being the norm for granule cells in the cell layer. However, in rodent epileptic tissue some granule cells have "basal" dendrites, making them bipolar (Spigelman et al., 1998; Buckmaster and Dudek, 1999). Furthermore, other species or other nonepileptic preparations have demonstrated that granule cells can develop basal dendrites (Seress and Pokorny, 1981; Lübbers and Frotscher, 1987; Seress and Mrzljak, 1987; Isokawa et al., 1993). Therefore, the presence of basal dendrites on granule-like cells does not distinguish them greatly from granule cells in the cell layer.

Thus, there were few clear differences between granule-like cells and granule cells. Perhaps the one obvious difference was the regular epileptiform bursts of granule-like cells (see below).

\section{Spontaneous bursts of area CA3 pyramidal cells in pilocarpine-treated rats with seizures}

One of the surprising findings in this study was that area CA3 pyramidal cells had periodic synchronous bursts in slices from pilocarpine-treated rats after status and spontaneous seizures. This was surprising because previously studies of pilocarpine-treated rats have not described this activity (Isokawa, 1996a,b; Bausch and Chavkin, 1997; Molnár and Nadler, 1999 Okazaki et al., 1999), probably because they focused on the dentate gyrus only or there was more CA3 damage. However, such activity is a common finding in acute hippocampal slices that are exposed to convulsants, including pilocarpine (Wong and Traub, 1983; Swann and Brady, 1984; Ault et al., 1986; Chestnut and Swann, 1988; Müller and Misgeld, 1991; Perreault and Avoli, 1991; Nagao et al., 1994; Lee et al., 1995b; Rutecki and Yang, 1998; Smith et al., 1998). It also has been noted that CA3 sharp waves (Buzsáki, 1986), a form of synchronized CA3 activity, occurs in epileptic tissue (Buzsáki et al., 1989). 


\section{Granule-like neurons were synchronized with area CA3 epileptiform bursts}

As mentioned above, one clear difference between granule-like cells and granule cells in the cell layer was spontaneous bursts of granule-like neurons that were synchronized with area CA3 population bursts. In some cases the synchrony was close enough so that ephaptic interactions or gap junctions may have been the underlying substrate. However, in other cases synchrony was not tight, suggesting polysynaptic mechanisms.

The synchronized activity could contribute mechanistically to the generation of spontaneous limbic seizures that occur in these animals. This might occur if granule-like cells innervate granule cells of the granule cell layer, which is possible given their axon collaterals in the inner molecular layer. Thus, a spontaneous burst in a granule-like cell might trigger reverberatory excitatory activity in the sprouted network of granule cells. That could in turn lead to excitatory activity in CA3, via the mossy fiber innervation of CA3. Seizure-like activity could exit the hippocampus via CA1. However, both CA3 and granule-like neurons could also innervate interneurons and have indirect inhibitory effects, dampening seizure-like activity (Ribak and Peterson, 1991; Sloviter, 1992; Kotti et al., 1997).

At the present time it is too soon to say whether the granule-like cells, and their periodic bursts with CA3 pyramidal cells, play a role in the recurrent seizures of pilocarpine-treated rats. The net effect of the synchronous activity in CA3 and the hilar/CA3 border is likely to depend on several factors, including the extent of cell loss, sprouting of any of the residual cell types onto other neurons, changes in excitatory/inhibitory receptors after seizures (Rice et al., 1996; Kapur and Macdonald, 1997; Brooks-Kayal et al., 1998) and the myriad of other effects that seizures produce (Sheng and Greenberg, 1990; Gall, 1993; Lynch et al., 1996).

One argument against a critical role in epileptogenesis comes from a study of seizure-induced neurogenesis in pilocarpinetreated rats (Parent et al., 1999). It was shown that recurrent seizures occurred after irradiation stopped seizure-induced neurogenesis in the subgranular zone (Parent et al., 1999). Although it was noted that some newly born cells in the hilus occurred despite irradiation, it is likely they were glia (Parent et al., 1999). These data suggest that granule-like cells at the hilar/CA3 border are not critical to limbic seizures in pilocarpine-treated rats. However, they could be a contributing factor, when present. They may also be important to other aspects of the epileptic condition, such as behavioral/cognitive deficits associated with seizures (Leite et al., 1990; Hermann et al., 1992; McNamara et al., 1992; Stafstrom et al., 1993; Sutula et al., 1995; Stubley-Weatherly et al., 1996). Granulelike cells may play a role in these abnormalities because of their ability to disrupt normal hippocampal signal processing in the trisynaptic pathway.

\section{The origin of granule-like neurons}

There are several hypotheses that could explain the origins of the granule-like cells at the hilar/CA3 border. Because some of the granule-like cells were labeled by BrdU, they could represent some of the new granule neurons that are born after seizure-induced neurogenesis (Bengzon et al., 1997; Parent et al., 1997, 1998; Gray and Sundstrom, 1998; Scott et al., 1998; Nakagawa et al. 2000).

Another hypothesis, which does not involve neurogenesis, is that granule-like cells are caused by abnormal migration of adult granule cells from the granule cell layer. This possibility seems unlikely given the lack of precedent for adult neurons to move to new locations in the mature brain. A third possibility would be that the normal hilar/CA3 cells (interneurons, mossy cells, CA3c pyramidal cells, and glia) develop a granule cell phenotype (morphologically and electrophysiologically) after seizures. This seems unlikely given the extensive physiological and morphological changes that would be involved.

\section{Relevance to other epileptic or nonepileptic conditions}

Other animal models of epilepsy besides those considered in the present study may also involve granule-like neurons, because several types of seizures or seizure-inducing stimuli can lead to increased granule cell neurogenesis and possible migration into the hilus. However, in other conditions, the appropriate milieu (including glia, growth factors, etc.; Lowenstein and Arsenault, 1996) may be different and not foster the development of the same cluster of granule-like cells at the hilar/CA3 border or the epileptiform bursts.

It will be valuable to examine human epileptic tissue for $\mathrm{CaBP}$ immunoreactivity, because the one study of CaBP immunoreactivity in human epileptics that has been published demonstrated $\mathrm{CaBP}$-immunoreactive neurons in the hilar region with morphological characteristics of granule cells, although it was pointed out that they could be interneurons (Sloviter et al., 1991).

Because a variety of events besides seizures can lead to increased dentate granule cell neurogenesis, granule-like neurons may also develop after other events besides seizures. Thus, changes in such diverse factors as stress (Cameron and Gould, 1994; Gould et al., 1997, 1998), learning (Gould et al., 1999), exercise (van Praag et al., 1999), environmental stimulation (Kempermann et al., 1998a,b), neurotransmitters and hormones (Cameron et al., 1995; Brezun and Dazsuta, 1999; Tanapat et al., 1999), lesions (Gould and Tanapat, 1997), or hypoxia/ischemia (Liu et al., 1998; BossenmeyerPourié et al., 1999) can result in alterations in neurogenesis in the dentate gyrus. A few hilar cells that have anatomical similarities to granule cells have been demonstrated in studies of ischemia (Hsu and Buzsáki, 1993) and mouse mutants (Robbins et al., 1999; Woodhams and Terashima, 1999), and many CaBP-immunoreactive hilar neurons have been reported after tetanus toxin injection (Lee et al., 1995a). Thus, granule-like neurons may develop after a variety of normal and pathological events. Exactly which life events (normal or abnormal) trigger the development of granule-like neurons, how many are necessary to alter hippocampal function, and when this contributes to or counteracts neuropathology, are questions for future experiments.

\section{REFERENCES}

Acsády L, Kamondi A, Sik A, Freund T, Buzsáki G (1998) GABAergic cells are the major postsynaptic targets of mossy fibers in the rat hippocampus. J Neurosci 18:3386-3403.

Amaral DG (1978) A Golgi study of cell types in the hilar region of the hippocampus in the rat. J Comp Neurol 182:851-914.

Ault B, Gruenthal M, Armstrong DR, Nadler JV, Wang CM (1986) Baclofen suppresses bursting activity induced in hippocampal slices by differing convulsant treatments. Eur J Pharmacol 126:289-292.

Babb TL, Brown WJ (1987) Pathological findings in epilepsy. In: Surgical treatment of the epilepsies (Engel J, ed), pp 511-552. New York: Raven.

Babb TL, Kupfer WR, Pretorius JK, Crandall PH, Levesque MF (1991) Synaptic reorganization by mossy fibers in human epileptic fascia dentata. Neuroscience 42:351-363.

Baimbridge KG, Miller JJ (1982) Immunohistochemical localization of calcium binding protein in the cerebellum, hippocampal formation, and olfactory bulb of the rat. Brain Res 245:223-229.

Baimbridge KG, Miller JJ (1984) Hippocampal calcium binding protein during commissural kindling induced epileptogenesis: progressive decline and effects of anticonvulsants. Brain Res 324:85-90.

Baimbridge KG, Mody I, Miller JJ (1985) Reduction of rat hippocampal calcium binding protein following commissural amygdala, septal perforant path, and olfactory bulb kindling. Epilepsia 26:460-465.

Bausch SB, Chavkin C (1997) Changes in hippocampal circuitry after pilocarpine-induced seizures as revealed by opioid receptor distribution and activation. J Neurosci 17:477-492.

Ben-Ari Y (1985) Limbic seizures and brain damage produced by kainic acid: mechanisms and relevance to human temporal lobe epilepsy. Neuroscience 14:375-403. Bengzon J, Kokaia Z, Elmer E, Nanobashvile A, Kokaia M, Lindvall O
(1997) Apoptosis and proliferation of dentate gyrus neurons after single and intermittent limbic seizures. Proc Natl Acad Sci USA 94:10432-10437.

Blackstad TW, Kjaerheim A (1961) Special axo-dendritic synapse in hippocampal cortex: electron and light microscopic studies on the layer of mossy fibers. J Comp Neurol 117:113-159.

Bossenmeyer-Pourié C, Chihab R, Schroeder H, Daval JL (1999) Transient hypoxia may lead to neuronal proliferation in the developing mammalian brain: from apoptosis to cell cycle completion. Neuroscience 91:221-231. 
Brezun JM, Daszuta A (1999) Depletion in serotonin decreases neurogenesis in the dentate gyrus and the subventricular zone of adult rats. Neuroscience 89:999-1002.

Brooks-Kayal AR, Shumate MD, Jin H, Rikhter TY, Coulter DA (1998) Selective changes in single cell GABA(A) receptor subunit expression and function in temporal lobe epilepsy. Nat Med 4:1166-1172.

Buckmaster PS, Dudek FE (1997) Neuron loss, granule cell axon reorganization and functional changes in the dentate gyrus of epileptic kainatetreated rats. J Comp Neurol 385:385-404.

Buckmaster PS, Dudek FE (1999) In vivo intracellular analysis of granule cell axon reorganization in epileptic rats. J Neurophysiol 81:712-721.

Buckmaster PS, Schwartzkroin PA (1995) Physiological and morphological heterogeneity of dentate hilus interneurons in the gerbil hippocampus in vivo. Eur J Neurosci 7:1391-1402.

Buhl EH, Han Z-S, Lörinczi Z, Stezhka VV, Karnup SV, Somogyi P (1994) Physiological properties of anatomically identified axo-axonic cells in the rat hippocampus. J Neurophysiol 71:1289-1307.

Buzsáki G (1986) Hippocampal sharp waves: their origin and significance. Brain Res 398:232-252.

Buzsáki G, Pononmareff GL, Bayardo F, Ruiz R, Gage FH (1989) Neuronal activity in the subcortically denervated hippocampus: a chronic model for epilepsy. Neuroscience 28:527-538.

Cameron HA, Gould E (1994) Adult neurogenesis is regulated by adrenal steroids in the dentate gyrus. Neuroscience 61:203-209.

Cameron HA, McEwen BS, Gould E (1995) Regulation of adult neurogenesis by excitatory input and NMDA receptor activation in the dentate gyrus. J Neurosci 15:4687-4692.

Chestnut TJ, Swann JW (1988) Epileptiform activity induced by 4-aminopyridine in immature hippocampus. Epilepsy Res 2:187-193.

Chicurel ME, Harris KM (1992) Three-dimensional analysis of the structure and composition of CA3 branched dendritic spines and their synaptic relationships with mossy fiber boutons in the rat hippocampus. J Comp Neurol 325:169-192.

Claiborne BJ, Amaral DG, Cowan WM (1986) A light and electron microscopic analysis of the mossy fibers of the rat dentate gyrus. J Comp Neurol 246:435-458.

Dudek FE, Obenaus A, Schweitzer JS, Wuarin J-P (1994) Functional significance of hippocampal plasticity in epileptic brain: electrophysiological changes of the dentate granule cells associated with mossy fiber sprouting. Hippocampus 4:259-265.

Freund TF, Buzsáki G (1996) Interneurons of the hippocampus. Hippocampus 6:347-470.

Freund TF, Ylinen A, Miettinen R, Pitkänen A, Lahtinen H, Baimbridge KG, Riekkinen PJ (1991) Pattern of neuronal cell death in the rat hippocampus after status epilepticus. Relationship to calcium binding protein content and ischemic vulnerability. Brain Res Bull 28:27-38.

Frotscher M (1985) Mossy fibres form synapses with identified pyramidal basket cells in the CA3 region of the guinea-pig hippocampus: a combined Golgi-electron microscope study. J Neurocytol 14:245-259.

Frotscher M (1989) Mossy fiber synapses on glutamate decarboxylaseimmunoreactive neurons: evidence for feed-forward inhibition in the CA3 region of the hippocampus. Exp Brain Res 75:441-445.

Gaarskjaer FB, Laurberg S (1983) Ectopic granule cells of hilus fasciae dentatae projecting to the ipsilateral regio inferior of the rat hippocampus. Brain Res 24:1-16.

Gage FH, Kempermann G, Palmer TD, Peterson DA, Ray J (1998) Multipotent progenitor cells in the adult dentate gyrus. J Neurobiol $36: 249-266$

Gall CM (1993) Seizure-induced changes in neurotrophin expression: implications for epilepsy. Exp Neurol 124:150-166.

Gibbs JW, Shumate MD, Coulter DA (1997) Differential epilepsyassociated alterations in postsynaptic GABA(A) receptor function in dentate granule and CA1 neurons. J Neurophysiol 77:1924-1938.

Goodman JH, Scharfman HE (1999) Calbindin $\mathrm{D}_{28 \mathrm{~K}}(\mathrm{CaBP})$ - immunoreactive (IR) granule-like neurons in the hilus of the rat dentate gyrus after status epilepticus (SE). Epilepsia 40:35.

Goodman JH, Wasterlain CG, Massarweh WF, Dean E, Sollas AL, Sloviter RS (1993) Calbindin-D28k immunoreactivity and selective vulnerability to ischemia in the dentate gyrus of the developing rat. Brain Res 606:309-314.

Gould E, Cameron HA (1996) Regulation of neuronal birth, migration, and death in the rat dentate gyrus. Dev Neurosci 18:22-35.

Gould E, Tanapat P (1997) Lesion-induced proliferation of neuronal progenitors in the dentate gyrus of the adult rat. Neuroscience 80:427-436.

Gould E, McEwen BS, Tanapat P, Galea LAM, Fuchs E (1997) Neurogenesis in the adult tree shrew is regulated by psychosocial stress and NMDA receptor activation. J Neurosci 17:2492-2498.

Gould E, Tanapat P, McEwen BS, Flügge G, Fuchs E (1998) Proliferation of granule cell precursors in the dentate gyrus of adult monkeys is diminished by stress. Proc Natl Acad Sci USA 95:3168-3171.

Gould E, Beylin A, Tanapat P, Reeves A, Shors TJ (1999) Learning enhances adult neurogenesis in the hippocampal formation. Nat Neurosci 2:260-265.

Gray WP, Sundstrom LE (1998) Kainic acid increases the proliferation of granule cell progenitors in the dentate gyrus of the adult rat. Brain Res 790:52-59.
Hamlyn LH (1962) The fine structure of the mossy fiber endings in the hippocampus of the rabbit. J Anat 97:112-120.

Hellier JL, Patrylo PR, Buckmaster PS, Dudek FE (1998) Recurrent spontaneous motor seizures after repeated low-dose treatment with kainate: assessment of a rat model of temporal lobe epilepsy. Epilepsy Res 31:73-84.

Hermann B, Wyler A, Somes G, Berry A, Dolan FL (1992) Pathological status of the mesial temporal lobe predicts memory outcome from left anterior temporal lobectomy. Neurosurgery 31:652-657.

Houser CR (1990) Granule cell dispersion in the dentate gyrus of humans with temporal lobe epilepsy. Brain Res 535:195-204.

Hsu M, Buzsáki G (1993) Vulnerability of mossy fiber targets in the rat hippocampus to forebrain ischemia. J Neurosci 13:3964-3979.

Isokawa M (1996a) Decreased time constant in hippocampal dentate granule cells in pilocarpine-treated rats with progressive seizures frequencies. Brain Res 718:169-175.

Isokawa M (1996b) Decrement of $\mathrm{GABA}_{\mathrm{A}}$ receptor-mediated inhibitory postsynaptic currents in dentate granule cells in epileptic hippocampus. J Neurophysiol 75:1901-1908.

Isokawa M, Levesque MF, Babb TL, Engel J (1993) Single mossy fiber axonal systems of human dentate granule cells studied in hippocampal slices from patients with temporal lobe epilepsy. J Neurosci 13:1511-1522.

Kapur J, Macdonald RL (1997) Rapid seizure-induced reduction of benzodiazepine and $\mathrm{Zn} 2+$ sensitivity of hippocampal dentate granule cell $\mathrm{GABA}_{\mathrm{A}}$ receptors. J Neurosci 17:7532-7540.

Kempermann G, Brandon EP, Gage F (1998a) Environmental stimulation of $129 / \mathrm{SvJ}$ mice causes increased cell proliferation and neurogenesis in the adult dentate gyrus. Curr Biol 8:939-942.

Kempermann G, Kuhn HG, Gage F (1998b) Experience-induced neurogenesis in the senescent dentate gyrus. J Neurosci 18:3206-3212.

Kotti T, Riekkinen PJ, Miettinen R (1997) Characterization of target cells for aberrant mossy fiber collaterals in the dentate gyrus of epileptic rat. Exp Neurol 146:323-330.

Lacaille JC, Kunkel DD, Schwartzkroin PA (1989) Electrophysiological and morphological characterization of hippocampal interneurons. In: The hippocampus: new vistas (Chan-Palay V, Köhler C, eds), pp 287306. New York: Alan R. Liss.

Lee CL, Rashid S, Swann JW (1995a) A novel population of calbindinD28k immunoreactive (CAL-ir) neurons in the dentate hilus following tetanus toxin (TT) induced seizures in early-life. Epilepsia 36:61.

Lee CL, Hrachovy RA, Smith KL, Frost JD, Swann JW (1995b) Tetanus toxin-induced seizures in infant rats and their effects on hippocampal excitability in adulthood. Brain Res 677:97-109.

Leite JP, Nakamura EM, Lemos T, Masur J, Cavalheiro EA (1990) Learning impairment in chronic epileptic rats following pilocarpineinduced status epilepticus. Braz J Med Biol Res 23:681-683.

Liu A, Nagao T, Desjardis GC, Gloor P, Avoli M (1994) Quantitative evaluation of neuronal loss in the dorsal hippocampus in rats with long-term pilocarpine seizures. Epilepsy Res 17:237-247.

Liu J, Solway K, Messing RO, Sharp FR (1998) Increased neurogenesis in the dentate gyrus after transient global ischemia in gerbils. J Neurosci 18:7768-7778

Lowenstein DH, Arsenault L (1996) The effects of growth factors on the survival and differentiation of cultured dentate gyrus neurons. J Neurosci 16:1759-1769.

Lowenstein DH, Miles MF, Hatam F, McCabe T (1991) Up regulation of calbindin-D28K mRNA in the rat hippocampus following focal stimulation of the perforant path. Neuron 6:627-633.

Lurton D, Cavalheiro EA (1997) Neuropeptide Y immunoreactivity in the pilocarpine model of temporal lobe epilepsy. Exp Brain Res 116:186-190.

Lübbers K, Frotscher M (1987) Fine structure and synaptic connections of identified neurons in the rat fascia dentata. Anat Embryol 77:1-14.

Lübke J, Frotscher M, Spruston N (1998) Specialized electrophysiological properties of anatomically identified neurons in the hilar region of the rat fascia dentata. J Neurophysiol 79:1518-1534.

Lynch MW, Rutecki PA, Sutula TP (1996) The effects of seizures on the brain. Curr Opin Neurol 9:97-102.

Maglóczky ZS, Halász P, Vajda J, Czirják S, Freund TF (1997) Loss of calbindin- $\mathrm{D}_{28 \mathrm{~K}}$ immunoreactivity from dentate granule cells in human temporal lobe epilepsy. Neuroscience 76:377-385.

Makiura Y, Suzuki F, Chevalier E, Onteniente B (1999) Excitatory granule cells of the dentate gyrus exhibit a double inhibitory neurochemical content after intrahippocampal administration of kainate in adult mice. Exp Neurol 159:73-83.

Margerison JH, Corsellis JAN (1966) Epilepsy and the temporal lobes: a clinical electroencephalographic and neuropathological study of the brain in epilepsy, with particular reference to the temporal lobes. Brain 399: $1246-1283$.

Markakis A, Gage FH (1999) Adult generated neurons in the dentate gyrus send axonal projections to field CA3 and are surrounded by synaptic vesicles. J Comp Neurol 406:449-460.

Mathern GW, Babb TL, Armstrong DL (1997) Hippocampal sclerosis. In: Epilepsy: a comprehensive textbook (Engel J, Pedley TA, eds), pp 133 156. Philadelphia: Lippincott-Raven.

Mathern GW, Pretorius JK, Mendoza D, Lozada A, Kornblum HI (1998) 
Hippocampal AMPA and NMDA mRNA levels correlate with aberrant fascia dentata mossy fiber sprouting in the pilocarpine model of spontaneous limbic epilepsy. J Neurosci Res 54:734-753.

McNamara RK, Kirkby RD, dePape GE, Corcoran ME (1992) Limbic seizures, but not kindling, reversibly impair place learning in the Morris water maze. Behav Brain Res 50:167-175.

Meldrum BS, Bruton CJ (1992) Epilepsy. In: Greenfield's neuropathology (Adams JH, Duchen LW, eds), pp 1246-1283. New York: Oxford UP.

Mello LEAM, Cavalheiro EA, Babb TL, Kupfer WR, Pretorius JK, Tan AM, Finch DM (1993) Circuit mechanisms of seizures in the pilocarpine model of chronic epilepsy: cell loss and mossy fiber sprouting. Epilepsia 34:985-995.

Molnár P, Nadler PM (1999) Mossy fiber-granule cell synapses in the normal and epileptic rat dentate gyrus studied with minimal laser photostimulation. J Neurophysiol 82:1883-1894.

Mott DD, Turner DA, Okazaki MM, Lewis DV (1997) Interneurons of the dentate-hilus border of the rat dentate gyrus: morphological and electrophysiological heterogeneity. J Neurosci 17:3990-4005.

Motte J, Fernandes MJ, Baram TZ, Nehlig A (1998) Spatial and temporal evolution of neuronal activation, stress and injury in lithium-pilocarpine seizures in adult rats. Brain Res 793:61-72.

Müller W, Misgeld U (1991) Picrotoxin- and 4-aminopyridine induced activity in hilar neurons in the guinea pig hippocampal slice. J Neurophysiol 65:141-147.

Nadler JV (1981) Kainic acid as a tool for the study of temporal lobe epilepsy. Life Sci 29:2031-2042.

Nagao T, Avoli M, Gloor P (1994) Interictal discharges in the hippocampus of rats with long-term pilocarpine seizures. Neurosci Lett 174:160-164

Nagerl UV, Mody I, Jeub M, Lie AA, Elger CE, Beck H (2000) Surviving granule cells of the sclerotic human hippocampus have reduced $\mathrm{Ca}(2+)$ influx because of a loss of calbindin-D(28k) in temporal lobe. J Neurosci 20:1831-1836.

Nakagawa E, Aimi Y, Yasuhara O, Tooyama I, Shimada M, McGeer PL, Kimura H (2000) Enhancement of progenitor cell division in the dentate gyrus triggered by initial limbic seizures in rat models of epilepsy. Epilepsia 41:10-18.

Obenaus A, Esclapez M, Houser CR (1993) Loss of glutamate decarboxylase mRNA-containing neurons in the rat dentate gyrus following pilocarpine-induced seizures. J Neurosci 13:4470-4485.

Okazaki MM, Evenson DA, Nadler JV (1995) Hippocampal mossy fiber sprouting and synapse formation after status epilepticus in rats: visualization after retrograde transport of biocytin. J Comp Neuro 352:515-534.

Okazaki MM, Molnar P, Nadler JV (1999) Recurrent mossy fiber pathway in rat dentate gyrus: synaptic currents evoked in presence and absence of seizure-induced growth. J Neurophysiol 81:1645-1660.

Parent JM, Yu TW, Leibowitz RT, Geschwind DH, Sloviter RS, Lowenstein DH (1997) Dentate granule cell neurogenesis is increased by seizures and contributes to aberrant network reorganization in the adult rat hippocampus. J Neurosci 17:3727-3728.

Parent JM, Janumpalli S, McNamara JO, Lowenstein DH (1998) Increased dentate granule cell neurogenesis following amygdala kindling in the adult rat. Neurosci Lett 247:9-12.

Parent JM, Tada E, Fike JR, Lowenstein DH (1999) Inhibition of dentate granule cell neurogenesis with brain irradiation does not prevent seizureinduced mossy fiber synaptic reorganization in the rat. J Neurosci 19:4508-4519.

Parra P, Gulyás AI, Miles R (1998) How many subtypes of inhibitory cells in the hippocampus? Neuron 20:983-993.

Perreault P, Avoli M (1991) Physiology and pharmacology of epileptiform activity induced by 4 -aminopyridine in rat hippocampal slices. J Neurophysiol 65:771-785.

Racine RJ (1972) Modification of seizure activity by electrical stimulation. II Motor seizure. Electroencephalogr Clin Neurophysiol 32:281-294.

Rami A, Brehier A, Thomasset M, Rabié A (1987) Cholecalcin (28-kDa calcium-binding protein in the rat hippocampus: development in normal animals and in altered thyroid states. Dev Biol 124:228-238.

Ribak CE, Peterson G (1991) Intragranular mossy fibers in rats and gerbils form synapses with the somata and proximal dendrites of basket cells in the dentate gyrus. Hippocampus 1:355-364.

Rice A, Rafiq A, Shapiro SM, Jakoi ER, Coulter DA, DeLorenzo RJ (1996) Long-lasting reduction of inhibitory function and gammaaminobutyric acid type A receptor subunit mRNA expression in a model of temporal lobe epilepsy. Proc Natl Acad Sci USA 93:9665-9669.

Robbins CA, Wenzel HJ, Tsai L-H, Schwartzkroin PA (1999) Structural organization and function in dentate gyrus of the p35 mutant model associated with spontaneous seizures. Epilepsia 40:34.

Rutecki PA, Yang Y (1998) Ictal epileptiform activity in the CA3 region of hippocampal slices produced by pilocarpine. J Neurophysiol 79:3019-3029.

Sandler R, Smith AD (1991) Coexistence of GABA and glutamate in mossy fiber terminals of the primate hippocampus: an ultrastructural study. J Comp Neurol 303:177-192.

Scharfman HE (1992) Differentiation of rat dentate neurons by morphology and electrophysiology in hippocampal slices: granule cells, spiny hilar cells and aspiny, "fast-spiking" cells. In: The dentate gyrus and its role in seizures (Ribak CE, Gall CM, Mody I, eds), pp 99-109. New York: Elsevier.

Scharfman HE (1993) Spiny neurons of area CA3c in rat hippocampal slices have similar electrophysiological properties and synaptic responses despite morphological variation. Hippocampus 3:9-28.

Scharfman HE (1994) EPSPs of dentate gyrus granule cells synchronized with epileptiform bursts of dentate hilar mossy cells and area CA3 pyramidal cells in disinhibited rat hippocampal slices. J Neurosci 14:6041-6057.

Scharfman HE (1995a) Electrophysiological diversity of pyramidalshaped neurons at the granule cell layer/hilus border of the rat dentate gyrus recorded in vitro. Hippocampus 5:287-305.

Scharfman HE (1995b) Electrophysiological evidence that dentate hilar mossy cells innervate both granule cells and interneurons. J Neurophysiol 74:179-194.

Scharfman HE (1999) The role of nonprincipal cells in dentate gyrus excitability and its relevance to animal models of epilepsy and temporal lobe epilepsy. In: Basic mechanisms of the epilepsies: molecular and cellular approaches, Ed 3 (Delgado-Esqueta AV, Wilson, WA, Olsen RA, Porter RJ, eds), pp 805-820. New York: Lippincott-Raven.

Scharfman HE, Schwartzkroin PA (1988) Electrophysiology of morphologically identified mossy cells of the rat dentate hilus. J Neurosci 8:3412-3421.

Scharfman HE, Goodman JH, Sollas AL (1999a) Actions of BDNF in slices from rats with spontaneous seizures and mossy fiber sprouting in the dentate gyrus. J Neurosci 19:5619-5631.

Scharfman HE, Goodman JH, Sollas AL (1999b) Granule-like hilar neurons in pilocarpine-treated rats and their synchronization with CA3 pyramidal neurons. Epilepsia 40:156.

Schwarzer C, Sperk G (1995) Hippocampal granule cells express glutamic acid decarboxylase-67 after limbic seizures in the rat. Neuroscience 69:705-709.

Scott BW, Wang S, Burnham WM, De Boni U, Wojtowicz JM (1998) Kindling induced neurogenesis in the dentate gyrus of the rat. Neurosci Lett 248:73-77.

Seress L, Pokorny J (1981) Structure of the granular layer of the rat dentate gyrus. A light microscopic and Golgi study. J Anat 133:181-195.

Seress L, Mrzljak L (1987) Basal dendrites of granule cells are normal features of the fetal and adult dentate gyrus of both monkey and human hippocampal formation. Brain Res 405:169-174.

Seress L, Gulyás AI, Ferrer I, Tunon T, Soriano E, Freund TF (1993) Distribution, morphological features, and synaptic connections of parvalbumin-and calbindin- $\mathrm{D}_{28 \mathrm{~K}}$ immunoreactive neurons in the human hippocampal formation. J Comp Neurol 337:208-230.

Sheng M, Greenberg ME (1990) The regulation and function of c-fos and other immediate early genes in the nervous system. Neuron 4:477-485.

Shetty AK, Turner DA (1995) Intracerebroventricular kainic acid administration in adult rat alters hippocampal calbindin and nonphosphorylated neurofilament expression. J Comp Neurol 363:581-599.

Sloviter RS (1989) Calcium binding protein (Calbindin- $\mathrm{D}_{28 \mathrm{k}}$ ) and parvalbumin immunocytochemistry: localization in the rat hippocampus with specific reference to the selective vulnerability of hippocampal neurons to seizure activity. J Comp Neurol 280:183-196.

Sloviter RS (1991) Permanently altered hippocampal structure, excitability, and inhibition after experimental status epilepticus in the rat: the "dormant basket cell" hypothesis and its possible relevance to temporal lobe epilepsy. Hippocampus 1:41-66.

Sloviter RS (1992) Possible functional consequences of synaptic reorganization in the dentate gyrus of kainate treated rats. Neurosci Lett 127:91-96.

Sloviter RS, Sollas AL, Barbaro NM, Laxer KD (1991) Calcium-binding protein (Calbindin- $\mathrm{D}_{28 \mathrm{~K}}$ ) and parvalbumin immunocytochemistry in the normal and epileptic human hippocampus. J Comp Neurol 308:381-396.

Sloviter RS, Dichter MA, Rachinsky TL, Dean E, Goodman JH, Sollas AL, Martin DL (1996) Basal expression and induction of glutamate decarboxylase and GABA in excitatory granule cells of the rat and monkey hippocampal dentate gyrus. J Comp Neurol 373:593-618.

Smith KL, Lee CL, Swann JW (1998) Local circuit abnormalities in chronically epileptic rats after intrahippocampal tetanus toxin injection in infancy. J Neurophysiol 79:106-16.

Smith KL, Szarowski DH, Turner JN, Swann JW (1995) Diverse neuronal populations mediate local circuit excitation in area CA3 of developing hippocampus. J Neurophysiol 74:650-672.

Sperk G (1994) Kainic acid seizures in the rat. Prog Brain Res 42:1-32. Sperk G, Marksteiner J, Gruber B, Bellmann R, Mahata M, Ortler M (1992) Functional changes in neuropeptide $Y$ and somatostatin containing neurons induced by limbic seizures in the rat. Neuroscience 50:831-846.

Sperk G, Bellmann R, Gruber B, Greber S, Marksteiner J, Roder C, Rupp E (1996) Neuropeptide Y expression in animal models of temporal lobe epilepsy. Epilepsy Res [Suppl] 12:197-203.

Spigelman I, Yan X-X, Obenaus A, Lee Y-S, Wasterlain CG, Ribak CE (1998) Dentate granule cells form novel basal dendrites in a rat model of temporal lobe epilepsy. Neuroscience 86:109-120.

Spruston N, Johnston D (1992) Perforated patch clamp analysis of passive membrane properties of three classes of hippocampal neurons. J Neurophysiol 67:508-529. 
Stafstrom CE, Chronopoulos A, Thurber S, Thompson JL, Holmes GL (1993) Age-dependent cognitive and behavioral deficits after kainic acid seizures. Epilepsia 34:420-432.

Staley K, Otis T, Mody I (1992) Membrane properties of dentate gyrus granule cells: comparison of sharp microelectrode and whole-cell recordings. J Neurophysiol 67:1346-1358.

Sutula T, Cascino G, Cavazos J (1989) Mossy fiber synaptic reorganization in the epileptic human temporal lobe. Ann Neurol 26:321-330.

Sutula TP, Lauersdorf S, Lynch M, Jurgella C, Woodard A (1995) Deficits in radial arm maze performance in kindled rats: evidence for long-lasting memory dysfunction induced by repeated brief seizures. J Neurosci 15:8295-8301.

Sutula TP, Zhang P, Lynch M, Sayin U, Golarai G, Rod R (1998) Synaptic and axonal remodeling of mossy fibers in the hilus and supragranular region of the dentate gyrus in kainate-treated rats. J Comp Neurol 390:578-594.

Stubley-Weatherly L, Harding JW, Wright JW (1996) Effects of discrete kainic acid-induced hippocampal lesions on spatial and contextual learning and memory in rats. Brain Res 716:29-38.

Swann JW, Brady RJ (1984) Penicillin-induced epileptogenesis in immature rat CA3 hippocampal pyramidal cells. Dev Brain Res 12:243-254.

Tanapat P, Hastings NB, Reeves AJ, Gould E (1999) Estrogen stimulates a transient increase in the number of new neurons in the dentate gyrus of the adult female rat. J Neurosci 19:5792-5801.

Tauck DL, Nadler JV (1985) Evidence of functional mossy fiber sprouting in hippocampal formation of kainic acid treated rats. $\mathrm{J}$ Neurosc 5:1016-1022.
Tønder M, Kragh J, Bolwig T, Zimmer J (1994) Transient decrease in calbindin immunoreactivity of the rat fascia dentata granule cells after repeated electroconvulsive shocks. Hippocampus 4:79-84.

Tóth K, Freund TF (1992) Calbindin $\mathrm{D}_{28 \mathrm{~K}}$ containing nonpyramidal cells in the rat hippocampus: their immunoreactivity for GABA and projection to the medial septum. Neuroscience 49:793-805.

Turski L, Ikonomidou C, Turski WA, Bortolotto ZA, Cavalheiro EA (1989) Review: cholinergic mechanisms and epileptogenesis. The seizures induced by pilocarpine: a novel experimental model of intractable epilepsy. Synapse 3:154-171.

van Praag H, Kempermann G, Gage F (1999) Running increases cell proliferation and neurogenesis in the adult mouse dentate gyrus. Nat Neurosci 2:266-270.

Williamson A, Spencer DD, Shepherd GM (1993) Comparison between the membrane and synaptic properties of human and rodent dentate granule cells. Brain Res 622:194-202.

Wong RKS, Prince DA (1981) Afterpotential generation in hippocampal pyramidal cells. J Neurophysiol 45:86-97.

Wong RKS, Traub RD (1983) Synchronized burst discharge in disinhibited hippocampal slices. I Initiation in CA2-CA3 region. J Neurophysiol 49:442-458.

Woodhams PL, Terashima T (1999) Laminar boundaries persist in the hippocampal dentate molecular layer of the mutant shaking rat kawasaki despite aberrant granule cell migration. J Comp Neurol 409:57-70.

Yang Q, Wang S, Hamberger A, Celio MR, Haglid KG (1997) Delayed decrease of calbindin immunoreactivity in the granule cell-mossy fibers after kainic acid-induced seizures. Brain Res Bull 6:551-559. 